\title{
Insights and issues with simulating terrestrial DOC loading of Arctic river networks
}

\author{
David W. Kicklighter, ${ }^{1,5}$ Daniel J. Hayes, ${ }^{2,6}$ James W. McClelland, ${ }^{3}$ Bruce J. Peterson, ${ }^{1}$ A. David McGuire, ${ }^{4}$ \\ AND JERRY M. MELILLO ${ }^{1}$ \\ ${ }^{1}$ The Ecosystems Center, Marine Biological Laboratory, Woods Hole, Massachusetts 02543 USA \\ ${ }^{2}$ Institute of Arctic Biology, University of Alaska, Fairbanks, Alaska 99775 USA \\ ${ }^{3}$ Marine Science Institute, University of Texas at Austin, Port Aransas, Texas 78373 USA \\ ${ }^{4}$ U.S. Geological Survey, Alaska Cooperative Fish and Wildlife Research Unit, University of Alaska, Fairbanks, Alaska 99775 USA
}

\begin{abstract}
Terrestrial carbon dynamics influence the contribution of dissolved organic carbon (DOC) to river networks in addition to hydrology. In this study, we use a biogeochemical process model to simulate the lateral transfer of DOC from land to the Arctic Ocean via riverine transport. We estimate that, over the 20th century, the pan-Arctic watershed has contributed, on average, $32 \mathrm{Tg} \mathrm{C} / \mathrm{yr}$ of DOC to river networks emptying into the Arctic Ocean with most of the DOC coming from the extensive area of boreal deciduous needle-leaved forests and forested wetlands in Eurasian watersheds. We also estimate that the rate of terrestrial DOC loading has been increasing by $0.037 \mathrm{Tg} \mathrm{C} / \mathrm{yr}^{2}$ over the 20th century primarily as a result of climate-induced increases in water yield. These increases have been offset by decreases in terrestrial DOC loading caused by wildfires. Other environmental factors $\left(\mathrm{CO}_{2}\right.$ fertilization, ozone pollution, atmospheric nitrogen deposition, timber harvest, agriculture) are estimated to have relatively small effects on terrestrial DOC loading to Arctic rivers. The effects of the various environmental factors on terrestrial carbon dynamics have both offset and enhanced concurrent effects on hydrology to influence terrestrial DOC loading and may be changing the relative importance of terrestrial carbon dynamics on this carbon flux. Improvements in simulating terrestrial DOC loading to pan-Arctic rivers in the future will require better information on the production and consumption of DOC within the soil profile, the transfer of DOC from land to headwater streams, the spatial distribution of precipitation and its temporal trends, carbon dynamics of larch-dominated ecosystems in eastern Siberia, and the role of industrial organic effluents on carbon budgets of rivers in western Russia.
\end{abstract}

Key words: climate change; permafrost degradation; river discharge; riverine DOC export; terrestrial DOC loading; trajectory of the Arctic; water yield; wildfire.

\section{INTRODUCTION}

Pan-Arctic rivers have some of the highest concentrations of organic matter and rates of discharge among global rivers (Opsahl et al. 1999, Dittmar and Kattner 2003, McClelland et al. 2012). Although it represents only $1 \%$ of the global ocean volume, the Arctic Ocean is estimated to receive more than $10 \%$ of the global river discharge and dissolved organic matter. Furthermore, the pan-Arctic watershed is already experiencing a number of environmental changes including increases in surface air temperature, reduction in snow cover extent and duration, permafrost degradation and deep-

Manuscript received 9 June 2011; received 24 May 2012; accepted 30 May 2012. Corresponded Editor: J. E. Hobbie. For reprints of this Invited Feature, see footnote 1, p. 1743.

${ }^{5}$ E-mail: dkicklighter@mbl.edu

${ }^{6}$ Present address: Ecosystem Simulation Science Group, Environmental Sciences Division, Oak Ridge National Laboratory, Oak Ridge, Tennessee 37831 USA. ening of the active layer, changes in length or timing of the growing season, both increases and decreases in river discharge, alteration of wildfire and insect infestation regimes, shifts in vegetation cover, changes in photosynthetic activity, and changes in forest carbon storage (e.g., Peterson et al. 2002, Shvidenko and Nilsson 2002, Dye and Tucker 2003, Liski et al. 2003, Frauenfeld et al. 2004, McDonald et al. 2004, Payette et al. 2004, Déry et al. 2005, 2009, Goetz et al. 2005, Kasischke and Turetsky 2006, McClelland et al. 2006, Euskirchen et al. 2007, Soja et al. 2007). These environmental changes affect both the carbon dynamics and the hydrology of Arctic watersheds and thereby influence the transfer of carbon from terrestrial ecosystems to the neighboring river networks. Because the pan-Arctic region contains a large amount of carbon stored mostly in frozen soils (Tarnocai et al. 2009), it is important to understand how these changes may be influencing the release of terrestrial carbon to the oceans via river networks in 
addition to the release of carbon from the land to the atmosphere (e.g., Schuur et al. 2008, 2011),

While the land-to-atmosphere fluxes have received considerable attention because they directly affect terrestrial carbon storage, land-water interactions also influence the ability of terrestrial ecosystems to store carbon. Within a watershed, these land-water fluxes are relatively small when compared to the much larger fluxes associated with the uptake of atmospheric carbon dioxide during photosynthesis and the corresponding release of atmospheric carbon dioxide through decomposition and plant respiration. However, these landwater fluxes become more important to consider when assessing terrestrial carbon sequestration as the terrestrial loading of carbon to river networks may account for a large proportion of the carbon normally assumed to be sequestered by land ecosystems based on the net exchange of carbon between land and the atmosphere (e.g., Billett et al. 2004). Thus, a better understanding of land-water carbon fluxes is necessary to better evaluate terrestrial carbon sequestration and how it may change in the future.

In this study, we focus on how terrestrial carbon and water dynamics influence the allochthonous inputs of dissolved organic carbon (DOC) to pan-Arctic river networks. Dissolved organic carbon is formed by the incomplete decomposition of soil organic matter, the production of root exudates by vegetation, or the washout of organic compounds in throughfall (e.g., Aikenhead-Peterson et al. 2003, Michalzik et al. 2003). Before reaching a river network, however, soil DOC may undergo further decomposition to carbon dioxide or methane (Qualls and Haines 1992, Yano et al. 2000) or may be adsorbed onto particles of mineral soil (e.g., Aikenhead-Peterson et al. 2003, Kahle et al. 2004).

The presence of permafrost, which covers about $80 \%$ of the pan-Arctic watershed (Frey and McClelland 2009), and its degradation have rather unique effects on the loading of terrestrial DOC to river networks. First, infiltration of rain and snowmelt is limited by frozen ground during the spring, causing more run-off to river networks carrying with it DOC from organically rich soil horizons along shallow flow paths. As summer progresses, the seasonally thawed active layer deepens so that the soil profile can store more water and evapotranspiration increases so that more soil water is lost to the atmosphere rather than lost to the neighboring river networks (Serreze et al. 2003). This decrease in seepage also limits DOC loading to the local streams and rivers. In addition, the seasonal deepening of the active layer creates a longer flow path such that DOC in seepage may decompose or be adsorbed onto mineral particles in the soil before reaching the river network (MacLean et al. 1999, Striegl et al. 2005, Petrone et al. 2006, Prokushkin et al. 2007). Second, permafrost degradation can expose formerly frozen peat and soil organic carbon to decomposition over longer periods (Finlay et al. 2006, Schuur et al. 2008) to potentially increase terrestrial DOC loading to river networks (Frey and Smith 2005), but may also cause a deeper active layer to potentially decrease DOC loading by increasing the flow path as we have described.

Riverine DOC concentration and/or export has been found to be related to the amount and quality of litter and soil organic matter, vegetation cover (especially wetlands and peatlands), air temperature, precipitation and drought, river discharge, atmospheric carbon dioxide concentration, atmospheric nitrogen deposition, acid precipitation, topography (i.e., north-facing vs. south-facing slopes), agriculture, timber harvest, fire, and urbanization (e.g., Lamontagne et al. 2000, Neff and Hooper 2002, Worrall et al. 2004, AikenheadPeterson et al. 2005, Frey and Smith 2005, Striegl et al. 2005, Guo and Macdonald 2006, De Wit et al. 2007, Fenner et al. 2007, McClelland et al. 2007, Monteith et al. 2007, Raymond et al. 2007, Prokushkin et al. 2007, 2009, 2010, Sickman et al. 2007, Wilson and Xenopoulos 2008, Betts and Jones 2009). There has been considerable debate about the relative importance of these environmental factors on riverine DOC concentrations and export (Frey and Smith 2005, Striegl et al. 2005, Roulet and Moore 2006) as the sensitivity and even the direction of these relationships appears to vary among regions. In addition, interactions among these environmental factors may enhance or diminish terrestrial DOC loading based on their combined effects on plant productivity and/or decomposition of detritus and soil organic matter (e.g., Fenner et al. 2007) or their effects on modifying hydrologic flow paths (e.g., Petrone et al. 2006).

Process-based biogeochemistry models can be useful tools for examining the influence of environmental factors and their interactions on terrestrial carbon dynamics (Aufdenkampe et al. 2011). While many process-based terrestrial biogeochemical models have been applied to examine the influence of environmental factors on carbon fluxes between land and the atmosphere across the globe (e.g., McGuire et al. 2001, Friedlingstein et al. 2006, Sitch et al. 2007, Thornton et al. 2007, Sokolov et al. 2008, Zaehle et al. 2010), only McGuire et al. (2010) have used a process-based model to examine the influence of environmental factors on carbon fluxes between land and neighboring river networks across large regions. In this study, we expand upon the brief analysis presented in McGuire et al. (2010) by taking a closer look at how historical changes in atmospheric chemistry, climate, wildfires and human activities may have affected terrestrial carbon dynamics and hydrology to influence terrestrial DOC loading to the river networks within the pan-Arctic domain over the 20 th century.

\section{Methods}

Terrestrial loading of DOC to river networks depends on both the availability of DOC in the soil profile and the flux of water between land and river networks. To 
determine the availability of DOC in the soil profile, we have modified the version of the Terrestrial Ecosystem Model (TEM) used by Felzer et al. (2004) to include a DOC pool in the soil (Fig. 1) and we have developed algorithms to add and remove carbon from this DOC pool. Below, we first describe these model modifications followed by descriptions of how the modified model is parameterized and the development of regional estimates for the pan-Arctic. We then describe how TEM estimates are evaluated by comparisons to observed riverine DOC export and river discharge near the mouths of several large Arctic rivers. Finally, we describe a factorial simulation experiment that is used to determine the relative importance of various environmental factors $\left(\mathrm{CO}_{2}\right.$ fertilization, ozone pollution, atmospheric nitrogen deposition, climate, wildfire, agriculture and timber harvest) on terrestrial DOC loading and discharge of these Arctic rivers.

\section{Production of dissolved organic carbon}

In our simulations, the production of DOC (DOC-

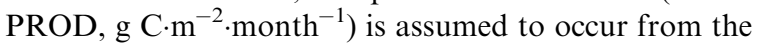
incomplete decomposition of litter and soil organic matter. Decomposition rates depend upon the same factors that influence heterotrophic respiration in earlier versions of TEM: the amount and quality of soil organic matter, soil temperature, and soil moisture (Raich et al. 1991, McGuire et al. 1997, Tian et al. 1999). As described in McGuire et al. (2010), the amount of DOC produced is assumed to be a proportion of the soil organic carbon that decomposes in a month. This proportion is assumed to vary by biome type. Because field data on the rates of decomposition, DOC production, and consumption prior to entering river networks are generally lacking and decomposition rates are assumed to equal rates of terrestrial net primary production (NPP) at equilibrium, we use estimates of NPP at intensively studied field sites and the corresponding DOC export rates in nearby rivers to estimate this DOC: decomposition model parameter for different biome types. As a result, the TEM parameterization implicitly accounts for the adsorption of DOC by mineral soil (Kalbitz et al. 2000, Neff and Asner 2001, Aikenhead-Peterson et al. 2003, Kahle et al. 2004) and any removal of DOC by hyporheic biota (e.g., Sobczak and Findlay 2002) as groundwater enters the river network. In addition, the TEM parameterization assumes that the new DOC pool represents only more refractory organic matter that does not undergo decomposition during its residence time in the soil profile (Qualls and Haines 1992). Thus, the labile components of DOC from throughfall, root exudates, and organic matter decomposition, which are not explicitly tracked through the ecosystem by TEM, are implicitly assumed to be part of the reactive soil organic carbon pool $\left(\mathrm{C}_{\mathrm{RS}}\right.$ in Fig. 1) if these components remain in the soil to decompose completely to carbon dioxide, but are also implicitly assumed to be part of the DOC

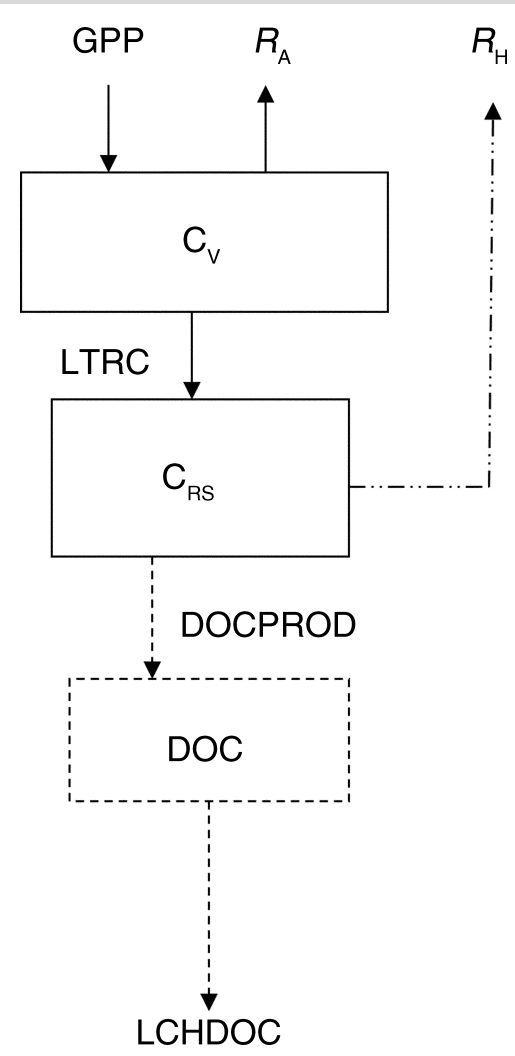

FIG. 1. Representation of carbon pools and fluxes in terrestrial ecosystems in the Terrestrial Ecosystem Model (TEM) 6.0. Carbon pools include vegetation carbon $\left(\mathrm{C}_{\mathrm{V}}\right)$, reactive soil organic carbon $\left(\mathrm{C}_{\mathrm{RS}}\right)$, and dissolved organic carbon (DOC). Carbon fluxes include gross primary productivity (GPP), autotrophic respiration $\left(R_{\mathrm{A}}\right)$, carbon in litterfall (LTRC), heterotrophic respiration $\left(R_{\mathrm{H}}\right)$, production of DOC (DOCPROD), and leaching of DOC from the ecosystem (LCHDOC). Solid boxes and arrows represent the carbon pools and fluxes already represented in TEM (Felzer et al. 2004). Dashed boxes and arrows represent the new carbon pool and fluxes added to TEM. Heterotrophic respiration $\left(R_{\mathrm{H}}\right)$ existed in previous versions of TEM but is now diminished by carbon now being redirected to DOCPROD.

pool that may be transferred to river networks during the spring flush (e.g., Holmes et al. 2008, Spencer et al. 2008).

Because decomposition is now assumed to be incomplete, less carbon is lost to the atmosphere as carbon dioxide from heterotrophic respiration in this version of TEM (TEM 6.0) than in earlier versions. Heterotrophic respiration is now determined by subtracting the amount of DOC produced from the rate of decomposition.

\section{Terrestrial DOC loading}

In TEM 6.0, DOC is assumed to be stored in the soil until it is mobilized by percolating water and leached from the soil based on the bulk concentration of DOC in soil water and the flux of water from soil to the neighboring river network. As indicated earlier, there is 
no attempt to simulate reductions in DOC concentration as soil water seeps through the soil profile (Neff and Asner 2001). The leaching of DOC depends on the runoff of rainwater (RRUN, m/month) and snowmelt (SRUN, m/month) from the soil profile, which are tracked separately in the model (Vörösmarty et al. 1989), and the concentration of DOC in the active layer. Water yield (WYLD, m/month) is determined as the sum of RRUN and SRUN. Thus, no DOC leaching occurs if no water yield is estimated to occur during a particular month. The leaching rate of DOC

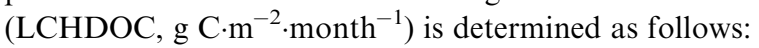

$$
\mathrm{LCHDOC}=[\mathrm{DOC}] \mathrm{WYLD}
$$

where $[\mathrm{DOC}]$ is the concentration of DOC in soil water $\left(\mathrm{g} / \mathrm{m}^{3}\right)$.

To better account for potential effects of permafrost dynamics on terrestrial DOC loading and water yield, we have also modified the representation of decomposition dynamics and soil moisture dynamics in TEM such that the availability of soil organic carbon to decomposition and soil moisture now depends on a seasonally varying active layer depth rather than a fixed rooting depth. In addition, we have also modified how TEM estimates disturbance effects on evapotranspiration and represents water storage in wetland ecosystems. The modifications are described in Appendix A. With these model modifications, more soil organic carbon becomes susceptible to decomposition during the growing season or with permafrost degradation as the active layer deepens. In addition, these modifications cause generally wetter conditions and more run-off associated with snow melt to occur in the spring, but allows more water to be stored in the soil profile during the summer.

While there is no attempt to explicitly account for the effects of overland flow vs. diffuse run-off (Futter and de Wit 2008) in our simulations, the variable active layer does allow us to simulate seasonal variations in hydrologic flow paths on DOC leaching. During the spring when the soil is mostly frozen, a small active layer fills up more easily with water so that most rain and melt water, along with the DOC found in the active layer, is directed to neighboring water bodies rather than remaining in the soil layer. Later, during the summer when the active layer is much deeper, more water and DOC remain in the soil rather than being directed toward neighboring water bodies.

\section{Model parameterization}

Although many of the model parameters are defined from published information, some are determined by calibrating the model to fluxes and pools of an intensively studied field site using averaged atmospheric chemistry and climate data for that site as model inputs (Raich et al. 1991). For most vegetation types used in this study, this information can be found in previous publications (Raich et al. 1991, McGuire et al. 1992, 2010, Clein et al. 2002, 2007, Zhuang et al. 2003,
Euskirchen et al. 2006, Hayes et al. 2011). The data used to calibrate the model for boreal needleleaf deciduous forest and wetlands, dominant ecosystems in the panArctic region, are provided in Appendix B. Calibration occurs when all annual carbon fluxes into the terrestrial ecosystems are within $1.0 \mathrm{~g} \mathrm{C} \cdot \mathrm{m}^{-2} \cdot \mathrm{yr}^{-1}$ of all annual carbon fluxes out of the ecosystem, all annual nitrogen fluxes into the ecosystem are within $0.02 \mathrm{~g} \mathrm{~N} \cdot \mathrm{m}^{-2} \cdot \mathrm{yr}^{-1}$ of all annual nitrogen fluxes out of the ecosystem, and all annual water fluxes into the ecosystem are within 0.01 $\mathrm{mm}$ of all annual water fluxes out of the ecosystem; i.e., equilibrium conditions. Under these conditions, net primary production is equal to decomposition (DOC$\mathrm{PROD}+R_{\mathrm{H}}$ [heterotrophic respiration]), DOC production (DOCPROD) is equal to DOC leaching (LCHDOC), and water yield is equal to precipitation minus evapotranspiration.

After calibration, the modified model is extrapolated across the pan-Arctic region to estimate the terrestrial loading of DOC and water yield to river networks emptying into the Arctic Ocean.

\section{Development of regional estimates}

We use the watershed boundary defined by Lammers et al. (2001) to determine the land areas that contribute DOC to the Arctic Ocean. The total area covers 24.2 million $\mathrm{km}^{2}$ of land in which 2276 river systems drain into the Arctic Ocean, Hudson Bay, and the northern Bering Sea and is represented by 21025 grid cells $\left(0.5^{\circ}\right.$ latitude $\times 0.5^{\circ}$ longitude). Terrestrial DOC loading is estimated for watersheds emptying into each of the 16 sea basins identified by Lammers et al. (2001) by summing the simulated LCHDOC estimates across the grid cells of the appropriate watersheds associated with the sea basins. Similarly, river discharge is determined by summing the simulated WYLD estimates across the grid cells of the appropriate watersheds.

To develop regional estimates of monthly terrestrial carbon, nitrogen, and water fluxes and pool sizes, TEM is driven by spatially referenced information on atmospheric chemistry, climate, elevation, soils, and land cover. Spatially explicit data sets have been assembled to cover the watersheds of the 16 sea basins (Lammers et al. 2001) for elevation based on the TerrainBase v1.1 data set of the National Geophysical Data Center, Boulder, Colorado, USA (NGDC 1994); soil texture from the Global Gridded Surfaces of Selected Soil Characteristics data set (GSDTG 2000); and undisturbed natural or "potential" vegetation from the Global Land Cover Characterization version 2 Seasonal Land Cover Regions data set (Loveland et al. 2000). In addition, spatially explicit time-series data sets have been developed for these watersheds for monthly accumulated hourly ozone levels above a threshold of $40 \mathrm{ppb}$ (AOT40 index) from Felzer et al. (2005); annual atmospheric nitrogen deposition from Van Drecht et al. (2003); monthly air temperature $\left({ }^{\circ} \mathrm{C}\right)$, precipitation $(\mathrm{mm})$ and incident solar radiation $\left(\mathrm{W} / \mathrm{m}^{2}\right.$, derived from cloudiness) 
from the Climate Research Unit (CRU) of the University of East Anglia (Mitchell and Jones 2005) along with NCEP/NCAR Reanalysis 1 data sets (NOAA-ESRL Physical Sciences Division, Boulder, Colorado, USA); and annual land cover based on potential vegetation (Loveland et al. 2000), wildfire distribution and severity from Balshi et al. (2007) and Sukhinin et al. (2004), and row-crop agriculture, pasture, and timber harvest data from Hurtt et al. (2006). All temporally explicit data has been backcasted to year 1001 to allow for the consideration of the effects of several fire return intervals on background terrestrial biogeochemistry. Finally, global annual mean atmospheric carbon dioxide concentrations from Keeling et al. (2009) are used to represent historical changes in atmospheric carbon dioxide concentrations over the study period. Details of the development of these input data sets have been described previously by Hayes et al. (2011).

To estimate carbon, nitrogen, and water fluxes and pools for each grid cell, the TEM is first run to equilibrium using mean monthly climate for the time period 1901 to 1930 and potential vegetation. Then, the model is applied to the spatial time-series data sets to estimate terrestrial carbon, nitrogen and water dynamics from the year 1001 to 2006. Because environmental conditions in our simulations are not necessarily appropriate to the time period from the year 1001 to 1900 , we limit our analysis of environmental effects on terrestrial DOC loading and water yield to the simulated results from the time period 1900 to 2006.

\section{Model evaluation}

To evaluate TEM estimates of terrestrial DOC loading and river discharge, we have delineated the watershed boundaries of six major rivers in Eurasia (Lena, Yenisei, Ob, Pechora, Northern Dvina, and Kolyma) and two major rivers in North America (Yukon, Mackenzie) from our gridded TEM results. Land cover characteristics of these river watersheds are provided in Appendix C. Terrestrial DOC loading for each river watershed is estimated by summing the simulated LCHDOC estimates across the grid cells of the watershed. Similarly, river discharge for each river watershed is determined by summing the simulated WYLD estimates across the grid cells of the watersheds.

The watershed estimates of annual terrestrial DOC loading developed by TEM are then compared to the appropriate annual estimates of DOC export reported by various studies for stations near the mouth of an Arctic river. Because most DOC export occurs in these pan-Arctic rivers during the spring freshet, we expect our watershed estimates of terrestrial DOC loading to be very similar to the observations because the cold temperatures, turbidity, and decreased residence time of the spring freshet would limit in-stream decomposition of the terrestrially derived DOC (Holmes et al. 2008), photo-oxidation, and the in-stream production of
DOC. However, our terrestrial DOC loading estimates would overestimate riverine DOC export if in-stream processing of the allochthonous DOC (e.g., decomposition, burial, photo-oxidation [Tranvik et al. 2009]) is significant and underestimate export if in-stream DOC production (e.g., Zou et al. 2006) is significant during other periods of the year.

The estimates of annual river discharge developed by TEM are compared to the appropriate annual river discharge reported by various studies for stations near the mouth of an Arctic river. This comparison assumes that evaporation from the rivers and lakes, melting of glaciers and ice fields (Dyurgerov and Carter 2004), inter-watershed transfers, and dam operations have minimal effects on annual river discharge. As different studies recorded observations over different time periods, we have chosen the TEM estimates from the appropriate time periods to match those of the observations from the various studies during the comparisons.

\section{Assessment of relative importance of environmental factors}

Because terrestrial DOC loading is dependent upon the underlying hydrology, we examine how environmental factors influence simulated estimates of both terrestrial DOC loading and river discharge. To quantify the relative importance of various environmental factors on terrestrial DOC loading and river discharge across the pan-Arctic watershed, we have conducted a series of seven model simulations (Table 1). In the first simulation (S1), we examine the effects of $\mathrm{CO}_{2}$ fertilization on terrestrial DOC loading and river discharge by allowing only atmospheric $\mathrm{CO}_{2}$ concentrations to increase over the study period; atmospheric nitrogen deposition and AOT40 are maintained at their 1900 levels throughout the simulation; climate variables are represented by mean monthly climate averaged over the period 1901 to 1930; and land cover is assumed to be potential vegetation with no fire disturbance, no food or timber harvest, and no land-use change. With each successive simulation (S2 through S7), we allow an additional environmental factor to vary over the study period based on gridded time-series data sets until all seven environmental factors are changing over the study period. Thus, simulations S1 thru S4 are based on undisturbed potential vegetation. This approach allows us to detect not only the direct effects of the environmental factors on DOC loading and river discharge, but also any interactive effects associated with environmental factors considered in earlier simulations.

Because the influence of environmental factors on terrestrial DOC loading and river discharge may not be linear, we examine potential temporal changes in the influence of environmental factors by studying how cumulative carbon and water fluxes over a period of time may change. To determine the cumulative influence of various environmental factors on DOC loading over 
TABle 1. Design of Terrestrial Ecosystem Model (TEM) simulation experiments used to analyze the influence of different environmental factors on terrestrial DOC loading and river discharge over the pan-Arctic watershed.

\begin{tabular}{|c|c|c|c|}
\hline Simulation & Effects & $\begin{array}{l}\text { Variables allowed to } \\
\text { change }\end{array}$ & Source of data sets \\
\hline \multicolumn{4}{|c|}{ Atmospheric chemistry effects } \\
\hline S1 & $+\mathrm{CO}_{2}$ fertilization & $\begin{array}{l}\text { atmospheric } \mathrm{CO}_{2} \\
\text { concentration }\end{array}$ & Keeling et al. (2009) \\
\hline S2 & $\mathrm{S} 1+$ ozone pollution & AOT40 ozone index & Felzer et al. (2005) \\
\hline S3 & $\begin{array}{l}\mathrm{S} 2+\text { atmospheric } \mathrm{N} \\
\text { deposition }\end{array}$ & $\mathrm{NH}_{\mathrm{X}}$ and $\mathrm{NO}_{\mathrm{Y}}$ & Van Drecht et al. (2003) \\
\hline \multicolumn{4}{|l|}{ Climate effects } \\
\hline S4 & $\begin{array}{l}\mathrm{S} 3+\text { climate variability } \\
\text { and change }\end{array}$ & $\begin{array}{l}\text { air temperature, } \\
\text { precipitation, } \\
\text { solar radiation }\end{array}$ & $\begin{array}{l}\text { CRU (Mitchell and Jones, 2005); NCEP/ } \\
\text { NCAR Reanalysis } 1\end{array}$ \\
\hline \multicolumn{4}{|l|}{ Disturbance effects } \\
\hline S5 & $\mathrm{S} 4+$ wildfire & area burned & $\begin{array}{l}\text { Sukhinin et al. (2004); Flannigan and } \\
\text { Little (2005); Balshi et al. (2007); } \\
\text { Randerson et al. (2006); van der Werf } \\
\text { et al. (2006) }\end{array}$ \\
\hline S6 & S5 + timber harvest & area harvested & Hurtt et al. (2006) \\
\hline S7 & $\begin{array}{l}\text { S6 + agriculture (i.e., total } \\
\text { effects) }\end{array}$ & $\begin{array}{r}\text { row crop area, } \\
\text { pasture area }\end{array}$ & Hurtt et al. (2006) \\
\hline
\end{tabular}

the study period, we first determine a baseline terrestrial DOC loading based on the LCHDOC estimates for 1900 from the S1 simulation and assume that these rates remain constant over the study period. The influence of $\mathrm{CO}_{2}$ fertilization on terrestrial DOC loading is then determined by summing the LCHDOC estimates for the preceding years and subtracting the associated summed baseline LCHDOC estimates. The influence of other factors on terrestrial DOC loading is then determined by summing the LCHDOC estimates for the preceding years and subtracting the associated summed LCHDOC estimates from those of the preceding simulation. A similar approach is used to determine the cumulative influence of these environmental factors on river discharge.

To examine how changes in hydrology alone are influencing our estimates of terrestrial DOC loading, we determined monthly DOC concentrations from the LCHDOC and WYLD estimates of year 1900 and multiplied these concentrations by the WYLD estimates of the S7 simulation from years 1901 to 2006.

\section{RESULTS \\ Evaluation of terrestrial DOC loading and river discharge estimates}

While reasonable agreement $( \pm 25 \%)$ does occur between TEM-simulated annual DOC loading estimates and annual DOC export estimates derived from observations for the Yenisei and $\mathrm{Ob}$ river watersheds, the TEM-simulated annual DOC loading estimates appear to overestimate the annual DOC export in the Lena, Kolyma, and Mackenzie river watersheds, and underestimate the annual DOC export from the Yukon, Pechora, and Northern Dvina river watersheds (Table 2). To see if the biases in DOC loading and export could be explained by biases in the simulated hydrology, we also compare TEM estimates of annual river discharge to observations. Again, there is reasonable agreement $( \pm 25 \%)$ between simulated and observed annual discharge estimates for the Yenisei and Ob Rivers (Table 3), but there also appears to be reasonable agreement between simulated and observed annual river discharge for the Mackenzie, Northern Dvina, and Kolyma Rivers. In contrast, TEM estimates account for only $60-70 \%$ of the annual discharge of the Lena and Pechora Rivers, and only $30-40 \%$ of the annual discharge of the Yukon River.

To evaluate the ability of TEM to capture seasonal variations in DOC export, we compare the proportion of our simulated annual DOC loading that occurs during spring (May-June), summer/fall (July-October), and winter (November-April) for the years 1999-2006 to observations at six major Arctic rivers for the years 1999-2008 (Holmes et al. 2012). The TEM estimates that $38-54 \%$ of the annual terrestrial DOC loading to these Arctic rivers occurs during the 2 months normally associated with the spring freshet whereas Holmes et al. (2012) estimate that $32-63 \%$ of annual DOC export occurs during this time (Fig. 2). While these percentages are roughly similar, TEM overestimates the relative springtime contribution of DOC in the Lena, Ob, and Mackenzie rivers and underestimates the relative springtime contribution in the Yenisei, Kolyma, and Yukon rivers. These biases are related to similar biases in seasonal discharge estimated by TEM with the exception of the Lena River where the relative contribution of the spring freshet to annual discharge is underestimated (Fig. 2). More details of our model evaluation are provided Appendix C. 
TABLE 2. Comparison of TEM estimates of dissolved organic carbon (DOC) loading based on water yield (WYLD) alone and with terrestrial carbon dynamics $(\mathrm{WYLD}+\mathrm{C})$ to riverine DOC export estimated by other studies for large Arctic river basins.

\begin{tabular}{|c|c|c|c|c|}
\hline \multirow[b]{2}{*}{ River and data source } & \multirow[b]{2}{*}{ Time period } & \multirow{2}{*}{$\begin{array}{c}\text { DOC export } \\
\text { (Gg C/yr) }\end{array}$} & \multicolumn{2}{|c|}{ TEM DOC loading (Gg C/yr) } \\
\hline & & & WYLD & WYLD + C \\
\hline \multicolumn{5}{|l|}{ Eurasia } \\
\hline \multicolumn{5}{|l|}{ Lena River (2 $\left.448000 \mathrm{~km}^{2}\right)$} \\
\hline Raymond et al. (2007) & 2004-2005 & 5830 & 8940 & 9190 \\
\hline Gordeev and Kravchishina (2009) & 1970-1995 & 3600 & 8249 & 7618 \\
\hline Holmes et al. (2012) & $1999-2008$ & 5681 & $8098 \dagger$ & $8351 \dagger$ \\
\hline \multicolumn{5}{|l|}{ Yenisei River (2 $\left.594000 \mathrm{~km}^{2}\right)$} \\
\hline Köhler et al. (2003) & 1980-1999 & 4860 & 5271 & 5344 \\
\hline Raymond et al. (2007) & 2004-2005 & 4690 & 4857 & 5551 \\
\hline Gordeev and Kravchishina (2009) & 1970-1995 & 4860 & 5480 & 5133 \\
\hline Holmes et al. (2012) & 1999-2008 & 4645 & $4977 \dagger$ & $5386 \dagger$ \\
\hline \multicolumn{5}{|l|}{ Ob River $\left(2545000 \mathrm{~km}^{2}\right)$} \\
\hline Köhler et al. (2003) & 1980-1999 & 3120 & 3588 & 3913 \\
\hline Raymond et al. (2007) & 2004-2005 & 3050 & 3702 & 3856 \\
\hline Gordeev and Kravchishina (2009) & 1970-1995 & 3680 & 3640 & 3744 \\
\hline Holmes et al. (2012) & 1999-2008 & 4119 & 4104 & $4120 \dagger$ \\
\hline \multicolumn{5}{|l|}{ Pechora River $\left(324000 \mathrm{~km}^{2}\right)$} \\
\hline Gordeev and Kravchishina (2009) & $1970-1995$ & 1660 & 351 & 391 \\
\hline \multicolumn{5}{|l|}{ Northern Dvina River $\left(357000 \mathrm{~km}^{2}\right)$} \\
\hline Gordeev and Kravchishina (2009) & $1970-1995$ & 1280 & 281 & 367 \\
\hline \multicolumn{5}{|l|}{ Kolyma River $\left(647000 \mathrm{~km}^{2}\right)$} \\
\hline Gordeev and Kravchishina (2009) & $1970-1995$ & 740 & 907 & 910 \\
\hline Holmes et al. (2012) & $2000,2002-2004$ & 652 & 995 & 1044 \\
\hline \multicolumn{5}{|l|}{ North America } \\
\hline \multicolumn{5}{|l|}{ Yukon River (839000 km²) } \\
\hline Striegl et al. (2007) & $2001-2005$ & 1570 & 603 & 826 \\
\hline Raymond et al. (2007) & 2004-2005 & 1700 & 677 & 1037 \\
\hline Spencer et al. (2009) & 2004-2005 & 1750 & 677 & 1037 \\
\hline Holmes et al. (2012) & $2001-2008$ & 1454 & $623 \dagger$ & $852 \dagger$ \\
\hline Guo et al. (2012) & $2004-2005$ & $1620-2040$ & 677 & 1037 \\
\hline \multicolumn{5}{|l|}{ Mackenzie River $\left(1787000 \mathrm{~km}^{2}\right)$} \\
\hline Raymond et al. (2007) & 2004-2005 & 1400 & 2184 & 1855 \\
\hline Holmes et al. (2012) & 1999-2008 & 1377 & 1917 & $1668 \dagger$ \\
\hline
\end{tabular}

Note: Basin areas are in parentheses after river name.

$\uparrow$ Years 2001-2006 for Yukon River; 1999-2006 for other rivers

\section{Historical trends}

Overall, our simulations indicate that the land ecosystems of the pan-Arctic watershed contributed about $32 \mathrm{Tg} \mathrm{C} / \mathrm{yr}$ to the river networks emptying into the Arctic Ocean over the period 1900-2006. This value is slightly less than the range (33-40 $\mathrm{Tg} \mathrm{C} / \mathrm{yr}$ ) reported by other recent studies for riverine DOC export in the pan-Arctic (Raymond et al. 2007, Manizza et al. 2009, McGuire et al. 2009, Spencer et al. 2009, Holmes et al. 2012). However, our simulations indicate that terrestrial DOC loading across the pan-Arctic has been increasing at a rate of $0.037 \mathrm{TgC} / \mathrm{yr}^{2}(P<0.001, n=107)$ over the period 1900-2006 based on the slope of the nonparametric Kendall-Theil Robust Line (KTRL; Ziegler et al. 2003, Déry et al. 2005) and the Mann-Kendall test of significance (Ziegler et al. 2003). This change in terrestrial DOC loading rates is less than the $0.047 \mathrm{Tg} \mathrm{C} /$ $\mathrm{yr}^{2}$ reported in McGuire et al. (2010) even though it is based on the same simulation results due to the correction of a post-processing error that was subsequently discovered. A closer examination of the temporal trends (Fig. 3a), however, indicates that terrestrial DOC loading increased $0.087 \mathrm{Tg} \mathrm{C} / \mathrm{yr}^{2}$ between 1900-1963 (KTRL, $P<0.001, n=64$ ) and $0.084 \mathrm{Tg} \mathrm{C} / \mathrm{yr}^{2}$ between 1964 and $2006(\mathrm{KTRL}, P<$ $0.001, n=43$ ), with the exception of an offset in the early 1960 s, which is related to some exceptionally low annual mean air temperatures during this period (Fig. 3g). It is not clear if this decrease in air temperatures is "real" or an artifact of data processing. These temporal changes in terrestrial DOC loading are correlated (Spearman coefficient of rank correlations, $r$ [Sokal and Rohlf 1969]) with concurrent changes in river discharge (Fig. $3 \mathrm{~b}, r=0.660, P<0.001)$, heterotrophic respiration $\left(R_{\mathrm{H}}\right.$, Fig. 3c, $r=0.589, P<0.001$ ) and NPP (Fig. 3d, $r=$ $0.509, P<0.001)$ between 1900 and 1963, but are only correlated with changes in $R_{\mathrm{H}}(r=0.447, P<0.003)$ between 1964 and 2006. 
TABLE 3. Comparison of TEM estimates to observed river discharge rates by other studies for large pan-Arctic river basins.

\begin{tabular}{|c|c|c|c|}
\hline \multirow[b]{2}{*}{ River and data source } & \multirow[b]{2}{*}{ Time period } & \multicolumn{2}{|c|}{ River discharge $\left(\mathrm{km}^{3} / \mathrm{yr}\right)$} \\
\hline & & Observed & TEM \\
\hline \multicolumn{4}{|l|}{ Eurasia } \\
\hline \multicolumn{4}{|l|}{ Lena River (Laptev Sea) } \\
\hline Holmes et al. (2000) & $1936-1994$ & 533 & 370 \\
\hline Peterson et al. (2002) & $1936-1999$ & 530 & 369 \\
\hline McClelland et al. (2006) & $1964-2000$ & 538 & 365 \\
\hline Raymond et al. (2007) & $2004-2005$ & 610 & 370 \\
\hline Holmes et al. (2012) & $1999-2008$ & 582 & $346 \dagger$ \\
\hline \multicolumn{4}{|l|}{ Yenisei River (Kara Sea) } \\
\hline Holmes et al. (2000) & 1936-1995 & 577 & 495 \\
\hline Peterson et al. (2002) & $1936-1999$ & 620 & 494 \\
\hline McClelland et al. (2006) & $1964-2000$ & 583 & 483 \\
\hline Raymond et al. (2007) & 2004-2005 & 617 & 464 \\
\hline Holmes et al. (2012) & $1999-2008$ & 636 & $467 \dagger$ \\
\hline \multicolumn{4}{|l|}{ Ob River (Kara Sea) } \\
\hline Holmes et al. (2000) & $1936-1994$ & 404 & 389 \\
\hline Peterson et al. (2002) & $1936-1999$ & 404 & 388 \\
\hline McClelland et al. (2006) & $1964-2000$ & 407 & 385 \\
\hline Raymond et al. (2007) & $2004-2005$ & 353 & 378 \\
\hline Holmes et al. (2012) & $1999-2008$ & 427 & $425 \dagger$ \\
\hline \multicolumn{4}{|l|}{ Pechora River (Barents Sea) } \\
\hline Peterson et al. (2002) & $1936-1999$ & 141 & 95 \\
\hline Gordeev and Kravchishina (2009) & $1970-1995$ & 131 & 95 \\
\hline \multicolumn{4}{|l|}{ Northern Dvina River (Barents Sea) } \\
\hline Peterson et al. (2002) & $1936-1999$ & 105 & 102 \\
\hline Gordeev and Kravchishina (2009) & $1970-1995$ & 110 & 102 \\
\hline \multicolumn{4}{|l|}{ Kolyma River (East Siberian Sea) } \\
\hline Holmes et al. (2000) & $1936-1988$ & 71 & 106 \\
\hline Peterson et al. (2002) & $1936-1999$ & 132 & 103 \\
\hline McClelland et al. (2006) & $1964-2000$ & 98 & 97 \\
\hline Holmes et al. (2012) & $2000,2002-2004$ & 88 & 100 \\
\hline \multicolumn{4}{|l|}{ North America } \\
\hline \multicolumn{4}{|l|}{ Yukon River (Bering Strait) } \\
\hline Dornblaser and Striegl (2007) & 2001-2005 & 211 & 65 \\
\hline Striegl et al. (2007) & 1976-1995, 2001-2005 & 205 & 75 \\
\hline Raymond et al. (2007) & $2004-2005$ & 215 & 70 \\
\hline Holmes et al. (2012) & 2001-2008 & 206 & $67 \dagger$ \\
\hline \multicolumn{4}{|l|}{ Mackenzie River (Beaufort Sea) } \\
\hline McClelland et al. (2006) & $1964-2000$ & 307 & 236 \\
\hline Raymond et al. (2007) & $2004-2005$ & 286 & 230 \\
\hline Déry et al. (2009) & $1964-2007$ & 309 & 232 \\
\hline Holmes et al. (2012) & $1999-2008$ & 298 & $200 \dagger$ \\
\hline
\end{tabular}

Note: Associated Arctic sea basins are in parentheses after river name.

$\dagger$ Years 2001-2006 for Yukon River; 1999-2006 for other rivers.

River discharge increases at a rate of $4.6 \mathrm{~km}^{3} / \mathrm{yr}^{2}$ (KTRL, $P<0.001, n=107$ ) over the period 1900-2006 in our simulations. A closer examination of the temporal trends of the pan-Arctic river discharge estimates (Fig. $3 b)$, however, indicates that the trend in river discharge changes sometime during the mid-1960s such that river discharge increases at a rate of $6.9 \mathrm{~km}^{3} / \mathrm{yr}^{2}(\mathrm{KTRL}, P<$ $0.001, n=64)$ between 1900 and 1963 , but then begins to decrease at a rate of $6.0 \mathrm{~km}^{3} / \mathrm{yr}^{2}$ (KTRL, $P<0.05, n=$ 43) between 1964 and 2006. This change in river discharge trend is related to changes in the trends of both precipitation (Fig. 3h) and evapotranspiration
(Fig. 3f), which in turn, is related to changes in the warming trend (Fig. 3g). Precipitation increases at a rate of $10.1 \mathrm{~km}^{3} / \mathrm{yr}^{2}$ (KTRL, $P<0.001, n=64$ ) during the earlier time period, but then no significant trend is observed during the later time period. As a result, the larger increase in the rate of evapotranspiration during the later time period $\left(9.7 \mathrm{~km}^{3} / \mathrm{yr}^{2}\right.$, KTRL, $P<0.001, n=$ 43), as compared to the earlier time period $\left(4.2 \mathrm{~km}^{3} / \mathrm{yr}^{2}\right.$, KTRL, $P<0.001, n=63$ ), causes less moisture to be available for run-off during the later time period. The changes in evapotranspiration rates are related to changes in air temperature that increased by a rate of 


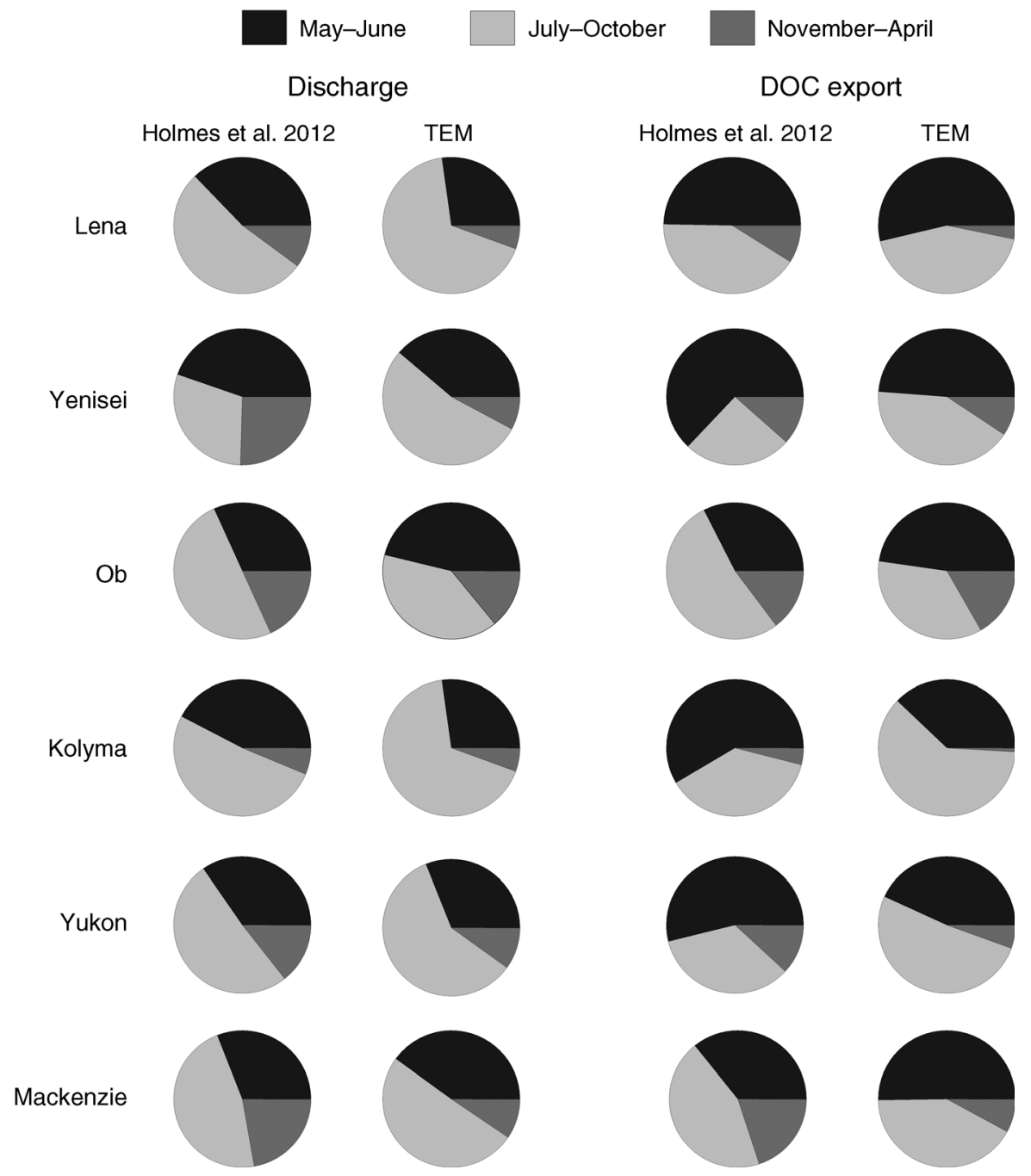

FIG. 2. Comparison of seasonal proportions of annual river discharge and riverine DOC export observed by Holmes et al. (2012) for six major Arctic rivers (listed on left) to TEM estimates.

only $0.1{ }^{\circ} \mathrm{C} / \mathrm{yr}$ (KTRL, $P<0.001, n=64$ ) before 1964 , but then increased at a rate of $0.4{ }^{\circ} \mathrm{C} / \mathrm{yr}(\mathrm{KTRL}, P<$ $0.001, n=43$ ) after 1964 .

Heterotrophic respiration increases at a rate of 6.50 Tg C $/ \mathrm{yr}^{2}$ (KTRL, $P<0.001, n=107$ ) over the period 1900-2006 in our simulations indicating an increase in decomposition of soil organic matter during this period. As NPP also increases at a rate of $7.16 \mathrm{Tg} \mathrm{C} / \mathrm{yr}^{2}(\mathrm{KTRL}$, $P<0.001, n=107$ ) over this same time period, the increases in decomposition over the 20th century are caused by a combination of an increase in soil organic matter from enhanced plant productivity, higher microbial metabolism from warmer temperatures (Fig. 3g), and the exposure of more soil organic matter to decomposition by a deepening of the active layer (Fig. $3 \mathrm{e})$. A closer examination of the temporal trends in $R_{\mathrm{H}}$ and NPP, however, indicates that the increases in these fluxes between 1964 and $2006\left(12.900 \mathrm{Tg} \mathrm{C} / \mathrm{yr}^{2}\right.$ for $R_{\mathrm{H}}$,
KTRL, $P<0.001, n=43 ; 12.571 \mathrm{Tg} \mathrm{C} / \mathrm{yr}^{2}$ for NPP, KTRL, $P<0.001, n=43)$ are about double those for the earlier period $\left(6.622 \mathrm{Tg} \mathrm{C} / \mathrm{yr}^{2}\right.$ for $R_{\mathrm{H}}$, KTRL, $P<$ $0.001, n=64 ; 6.233 \mathrm{Tg} \mathrm{C} / \mathrm{yr}^{2}$ for NPP, KTRL, $P<$ $0.001, n=64$ ) in response to concurrent changes in atmospheric carbon dioxide concentrations, atmospheric nitrogen deposition, and climate (Hayes et al. 2011). The trends in terrestrial DOC loading appear to be insensitive to the changes in trends in $R_{\mathrm{H}}$, NPP and river discharge over this time period.

\section{Relative importance of environmental factors}

Our simulations indicate that historical changes in environmental factors have enhanced cumulative terrestrial DOC loading by $258 \mathrm{Tg} \mathrm{C}$ during the study period between 1900 and 2006. Some environmental factors have increased the DOC loading whereas other factors have decreased it (Fig. 4). Similar to previous studies, 

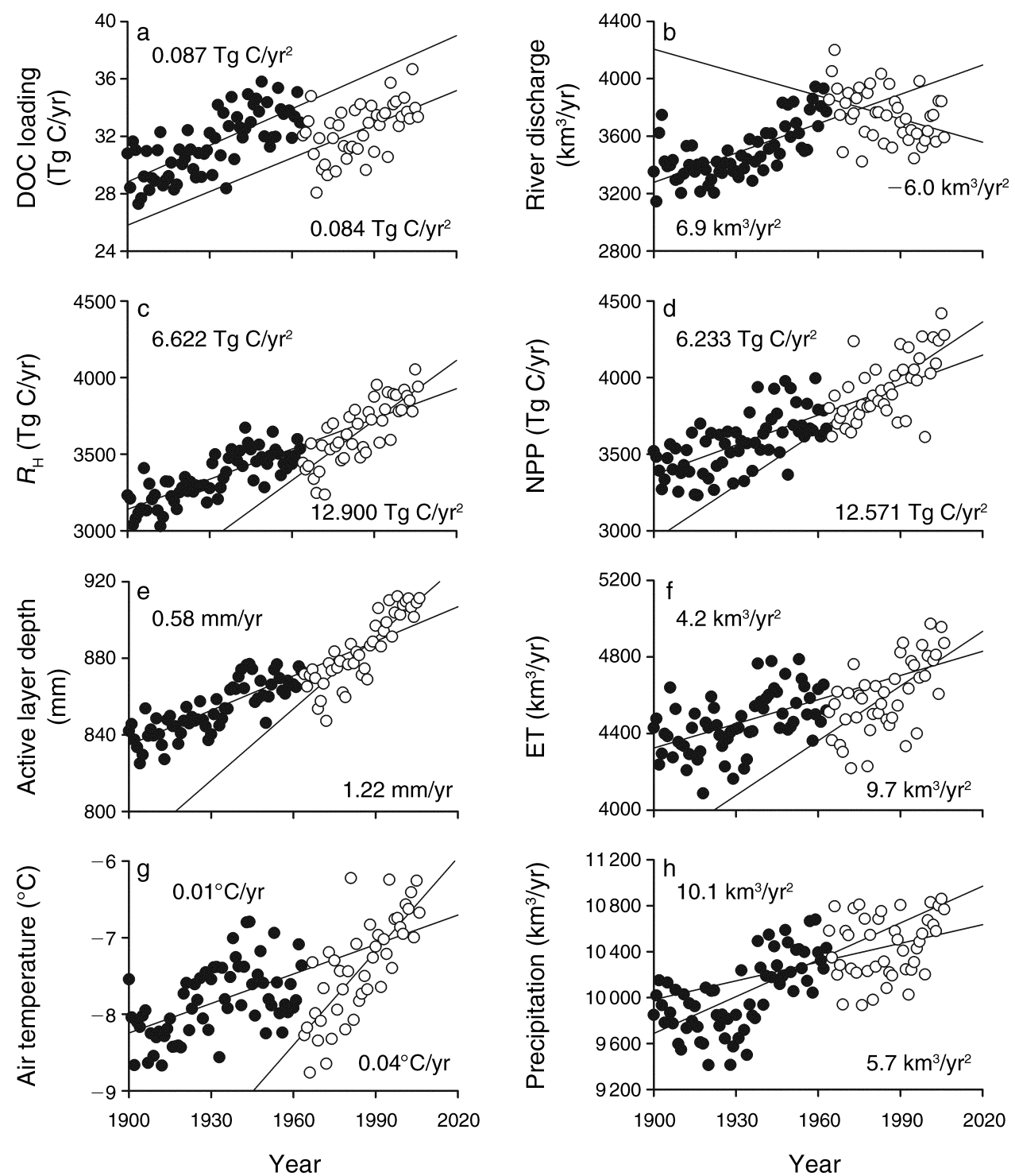

FIG. 3. Simulated changes in (a) terrestrial DOC loading, (b) river discharge, (c) terrestrial heterotrophic respiration $\left(R_{\mathrm{H}}\right)$, $(\mathrm{d})$ terrestrial net primary production (NPP), (e) mean maximum active layer depth, (f) evapotranspiration (ET), (g) air temperature, and $(\mathrm{h})$ precipitation across the pan-Arctic watershed over the period 1900-2006. Solid circles represent data used to determine trends from 1900 to 1963 whereas open circles represent data used to determine trends from 1964 to 2006 . Trends are represented by lines. The slope of each trend line between 1900 and 1963 is represented by the left value in each graph whereas the slope of each trend line between 1964 and 2006 is represented by the right value in each graph.

the increase in terrestrial DOC loading is correlated with concurrent increases in air temperature $(r=0.443, P<$ $0.001, n=107)$, atmospheric carbon dioxide concentration $(r=0.522, P<0.001, n=107)$, atmospheric nitrogen deposition $(r=0.529, P<0.001, n=107)$, and precipitation $(r=0.524, P<0.001, n=107)$. However, some factors are more important than others.

Most of the potential increase $(89.5 \%)$ in terrestrial DOC loading across the entire pan-Arctic watersheds is caused by historical changes in climate (i.e., precipitation, air temperature, and solar radiation). Agriculture and timber harvest have secondary effects and account for only $7.0 \%$ and $2.6 \%$ of the potential increase in terrestrial DOC loading, respectively. In contrast, fire decreases terrestrial DOC loading in our simulations and compensates for about $42.1 \%$ of the potential increases caused by climate, agriculture, and timber harvest. These results are consistent with Prokushkin et al. (2009) who found that DOC export from recently burned watersheds in central Siberia are only about $20 \%$ of the DOC export from watersheds burned 100 years ago and have had a chance to recover. Changes in atmospheric chemistry $\left(\mathrm{CO}_{2}\right.$ fertilization, ozone pollution, atmospheric nitrogen deposition) have had mini- 

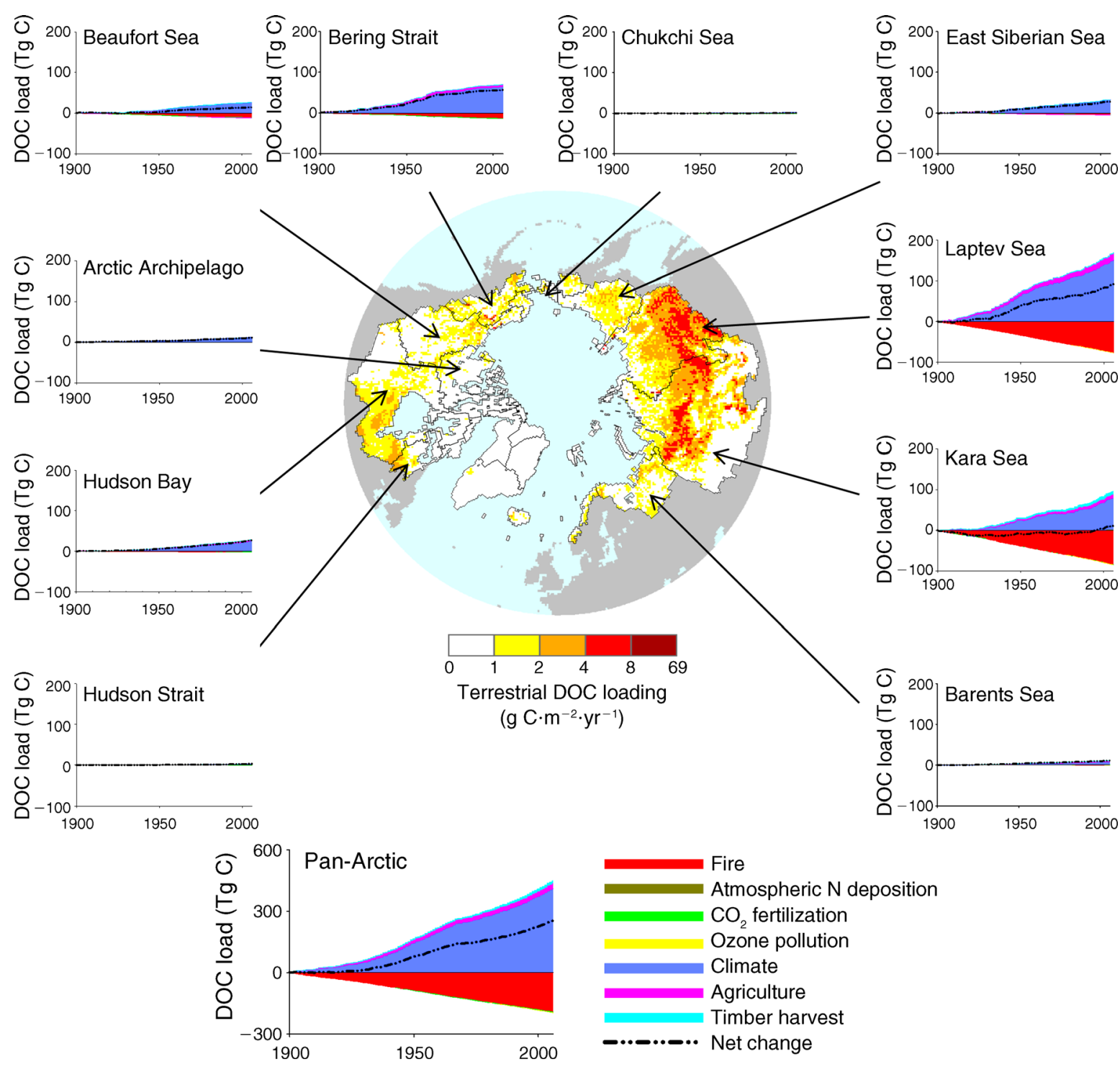

FIG. 4. Spatial variation in terrestrial DOC loading $\left(\mathrm{g} \mathrm{C} \cdot \mathrm{m}^{-2} \cdot \mathrm{yr}^{-1}\right)$ across the pan-Arctic watershed along with the relative effects of environmental factors on cumulative terrestrial DOC loading ( $\mathrm{Tg} \mathrm{C}$ ) in watersheds draining into Arctic sea basins over the period $1900-2006$.

mal direct effects on terrestrial DOC loading although interactions of these atmospheric chemistry variables with the other environmental factors may have contributed partially to the effects attributed to climate, wildfire, agriculture, and timber harvest based on the design of our simulation experiment.

Although terrestrial DOC loading is correlated with river discharge $(r=0.560, P<0.001, n=107)$, the effects of the environmental factors on terrestrial DOC loading do not always mimic the concurrent effects of these factors on the underlying hydrology (Fig. 5). Historical changes in the environmental factors have resulted in $32280 \mathrm{~km}^{3}$ of additional river discharge between 1900 and 2006 relative to the amount of discharge that would have occurred if conditions in 1900 were maintained. Similar to DOC loading, the historical changes in climate are responsible for most of this increase (94.0\%) over the study period with agriculture $(3.4 \%)$ and timber harvest $(2.1 \%)$ having secondary effects. Atmospheric chemistry (carbon dioxide, ozone, nitrogen deposition) has minimal effects on river discharge. In contrast to its large diminishing effects on terrestrial DOC loading, wildfire is responsible for only $1.8 \%$ of the increases in river discharge. These results are consistent with those of McClelland et al. (2004) who attributed increasing river discharge in Eurasian rivers between 1936 and 1999 mostly to concurrent increases in precipitation. 


\section{Regional variations}

The terrestrial contribution of DOC to river networks and eventually to the ocean is not uniform across the pan-Arctic region (Table 4). Most of this DOC, about $63 \%$, is contributed by rivers emptying into the Kara and Laptev Seas with the Yenisei and $\mathrm{Ob}$ Rivers dominating the DOC contributed to the Kara Sea (48\% and 35\%, respectively) and the Lena River dominating contributions to the Laptev Sea (82\%). While these watersheds are also reported to be the dominant contributors of DOC to the Arctic Ocean in other studies (e.g., Raymond et al. 2007, Manizza et al. 2009, Holmes et al. 2012), the relative contribution of DOC from the watersheds emptying into the Kara and Laptev Seas is less $(38-59 \%)$ than that estimated by TEM.

A comparison of the distribution of terrestrial DOC loading (Fig. 4) to the distribution of permafrost (Euskirchen et al. 2006, Schuur et al. 2008, Frey and McClelland 2009) indicates that the highest rates of DOC loading occur in those areas of Siberia with discontinuous and sporadic permafrost. These results are consistent with previous studies (Frey and Smith 2005, Prokushkin et al. 2011) that found higher riverine concentrations of DOC in catchments with less permafrost coverage than those with greater permafrost coverage in western and central Siberia.

Vegetation cover also has a large influence on the relative contribution of DOC to river networks in our simulations. Boreal needleleaf deciduous forests and forested wetlands, primarily in Eurasia, are responsible for about $48 \%$ of the DOC loading to pan-Arctic rivers overall. Other important biomes contributing DOC to pan-Arctic river networks include low shrub Arctic tundra and wetlands (22\%), and boreal needleleaf evergreen forest and forested wetlands (11\%). These latter biomes are the most important contributors of DOC in rivers emptying into the Hudson Bay, Beaufort Sea, Bering Strait, East Siberian Sea, and Barents Sea.

Similar to spatial variations in the magnitude of terrestrial DOC loading, the relative importance of the environmental factors also varies across the pan-Arctic domain (Fig. 4). The relative importance of the factors on DOC loading in the watersheds emptying into the Laptev Sea, which account for about $35.9 \%$ of the changes in DOC loading to the Arctic Ocean, mimics the relative importance for the entire pan-Arctic region (Fig. 4). In contrast, the reduction of DOC loading by wildfire compensates for most of the potential increase in terrestrial DOC loading by climate, agriculture, and timber harvest in the watersheds that empty into the Kara Sea such that these watersheds account for only $4.3 \%$ of the changes in DOC loading to the Arctic Ocean over the 20th century even though these watersheds account for about one-third of all the DOC delivered to the Arctic Ocean (Table 4). As a result, temporal changes in terrestrial DOC loading in the Bering Strait (21.8\%), the East Siberian Sea (10.7\%), and the Hudson
Bay $(10.5 \%)$ become more important even though they account for only $5.0 \%, 5.0 \%$, and $10.7 \%$, respectively, of all the DOC delivered to the Arctic Ocean over the study period. In these latter watersheds, climate dominated the effects of environmental factors on terrestrial DOC loading. The differences in the spatial and temporal patterns of environmental factors on river discharge (Fig. 5) and DOC loading (Fig. 4) among the various watersheds again indicate the importance of regional carbon dynamics on terrestrial DOC loading in addition to the underlying regional hydrology. Additional details of how regional variations in environmental factors have influenced terrestrial DOC loading and river discharge are provided in Appendix D.

\section{Discussion}

While our overall estimates of terrestrial DOC loading of pan-Arctic rivers are about the same magnitude as riverine DOC export to the Arctic Ocean determined by other studies, whose empirical estimates also have substantial uncertainties (e.g., Guo et al. 2012), discrepancies between model results and observations at several major pan-Arctic rivers indicate that a number of issues still need to be resolved before a terrestrial biogeochemistry model like TEM can reliably estimate the transfer of DOC between land and the Arctic Ocean.

\section{Model parameterization}

The overestimates of DOC export from the Lena River and the underestimates of DOC export from the Pechora and Northern Dvina Rivers appear to be at least partly associated with our model parameterizations and/or our simulated hydrology. Our parameterizations may have implicitly accounted for the influence of peatlands on simulated carbon dynamics in boreal needleleaf deciduous forests/wetlands, but not in tundra and boreal needleleaf evergreen forests/wetlands. The boreal needleleaf deciduous forests/wetlands parameterizations appear to be appropriate for the Yenisei and $\mathrm{Ob}$ River basins, but perhaps not the Lena River basin. Similarly, the tundra and boreal needleleaf evergreen forests/wetlands parameterizations appear to be more appropriate for the Mackenzie River basin than for the Pechora and Northern Dvina River basins. The introduction of organic effluents into the Pechora and Northern Dvina Rivers (Gordeev et al. 2006), may also have contributed to the discrepancies with model estimates as the TEM simulations do not account for industrial sources of organic inputs to river networks. However, the underestimate of annual DOC export in the Pechora River, along with the Yukon River, appears to be primarily associated with TEM underestimates of annual discharge in these rivers.

\section{The representation of hydrology}

A comparison of annual precipitation rates in Table 5 to the observed annual river discharge rates in Table 3 indicates that observed river discharge accounts for 80 

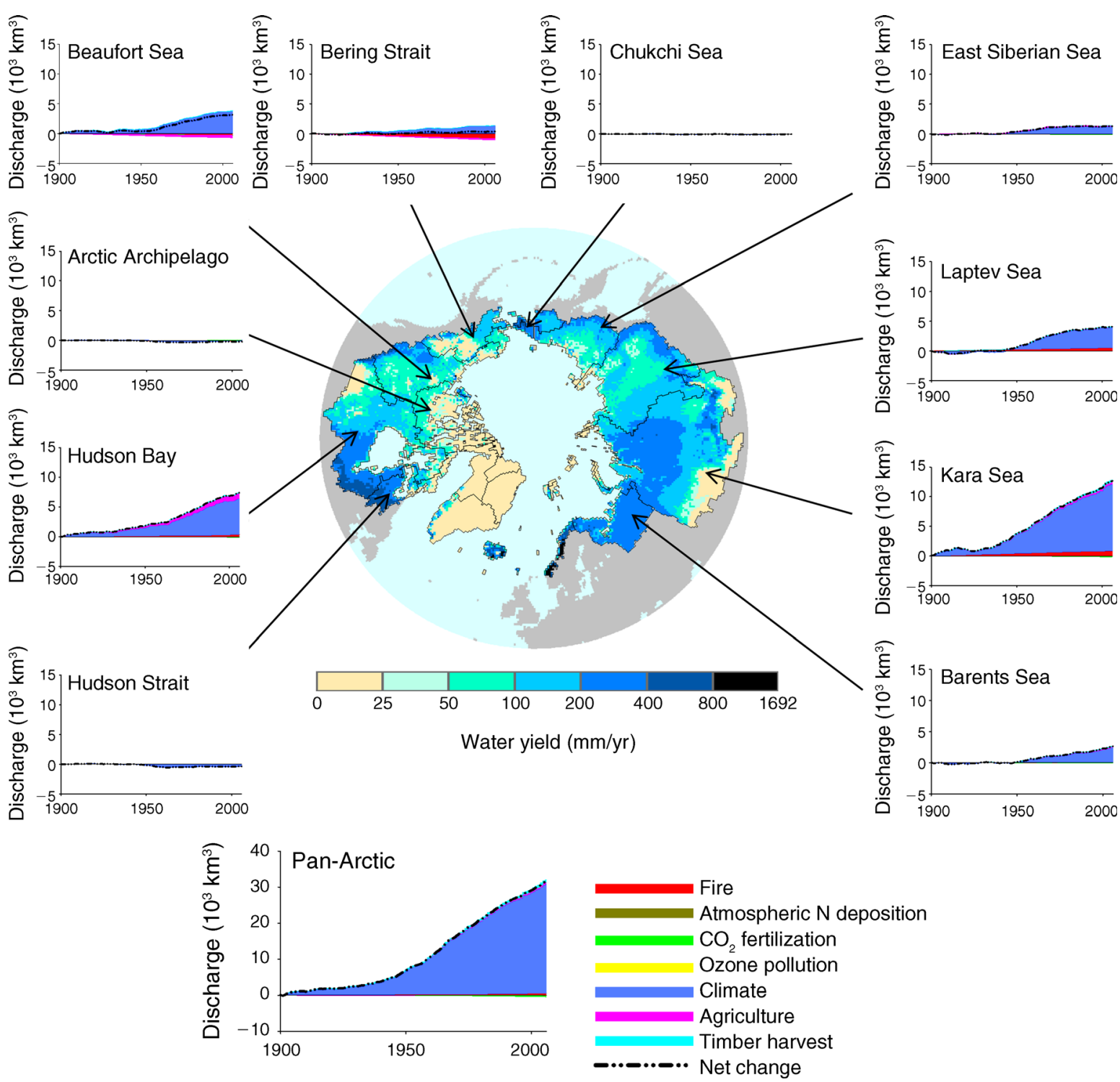

FIG. 5. Spatial variation in water yield $(\mathrm{mm} / \mathrm{yr})$ across the pan-Arctic watershed along with the relative effects of environmental factors on cumulative river discharge $\left(10^{3} \mathrm{~km}^{3}\right)$ from watersheds draining into Arctic sea basins over the period 1900-2006.

$100 \%$ of the prescribed precipitation in the Yukon and Pechora watersheds, but generally account for less than $60 \%$ of the prescribed precipitation in the watersheds of the other river networks. This result suggests that the CRU data set used to prescribe precipitation inputs is underestimating precipitation rates in the Yukon and Pechora watersheds. This underestimation of precipitation may be why TEM tends to underestimate discharge of the pan-Arctic rivers although ignoring glacial melt may also be a partial explanation for some watersheds such as the Yukon (Dyurgerov and Carter 2004).

With respect to monthly patterns of DOC loading, TEM estimates that the peak terrestrial DOC loading occurs during May and June in pan-Arctic rivers, with the exception of the Kolyma River, which peaks during
June and July, indicating that the model is indeed picking up the springtime flushing of terrestrial DOC from the landscape. The peak monthly discharge in these rivers, however, generally occurs about a month after the peak DOC loading. As TEM tends to underpredict both the relative contribution of DOC and discharge of the spring freshet in the Yenisei, Kolyma, and Yukon rivers, these results suggest that the simulated sizes of the snowpack in these watersheds, which depend on the CRU precipitation data sets described above, may be limiting the simulated contribution of water and DOC from land to river networks during the spring freshet.

Our simulations indicate that warming has increased evapotranspiration rates over the 20th century such that 
TABle 4. Precipitation $(P)$ and TEM estimates of evapotranspiration (ET), river discharge $(Q)$, and terrestrial DOC loading for watersheds draining into Arctic sea basins, based on water yield alone and with terrestrial carbon dynamics, for the period 1900 2006.

\begin{tabular}{|c|c|c|c|c|c|c|}
\hline \multirow[b]{2}{*}{ Sea basin } & \multicolumn{4}{|c|}{ Water $\left(\mathrm{km}^{3} / \mathrm{yr}\right)$} & \multicolumn{2}{|c|}{ "Terrestrial DOC loading (Gg C/yr) } \\
\hline & $P$ & ET & $P-\mathrm{ET}$ & $Q$ & WYLD & $\mathrm{WYLD}+\mathrm{C}$ \\
\hline Arctic Archipelago & 202 & 84 & 118 & 66 & 567 & 593 \\
\hline Arctic Subocean & 64 & 1 & 63 & 1 & 5 & 7 \\
\hline Baffin Bay & 203 & 2 & 201 & 4 & 14 & 12 \\
\hline Barents Sea & 722 & 292 & 430 & 352 & 1232 & 1352 \\
\hline Beaufort Sea & 688 & 426 & 262 & 241 & 2665 & 2062 \\
\hline Bering Strait & 350 & 186 & 164 & 154 & 1166 & 1600 \\
\hline Chukchi Sea & 65 & 24 & 41 & 38 & 183 & 223 \\
\hline East Siberian Sea & 336 & 170 & 166 & 175 & 1652 & 1601 \\
\hline Foxe Basin & 72 & 16 & 56 & 27 & 96 & 96 \\
\hline Greenland Sea & 256 & 1 & 255 & 3 & 5 & 4 \\
\hline Hudson Bay & 1667 & 880 & 787 & 597 & 3534 & 3420 \\
\hline Hudson Strait & 275 & 68 & 207 & 170 & 459 & 503 \\
\hline Kara Sea & 2867 & 1629 & 1238 & 1081 & 11152 & 10704 \\
\hline Laptev Sea & 1200 & 692 & 508 & 491 & 9676 & 9359 \\
\hline Norwegian Sea & 183 & 24 & 159 & 116 & 209 & 179 \\
\hline South Greenland & 1042 & 20 & 1022 & 79 & 207 & 155 \\
\hline Basins total & 10192 & 4515 & 5677 & 3595 & 32822 & 31868 \\
\hline
\end{tabular}

river discharge reaches a peak during the mid-1960s and begins to decline even though precipitation continues to increase. While our simulated trends in pan-Arctic river discharge between 1964 and 2006 appear to be consistent with similar decreases in observed river discharge from northern Canada over this time period (Déry and Wood 2005, Déry et al. 2005, McClelland et al. 2006), they are not consistent with the increasing discharge observed for the Eurasian rivers (McClelland et al. 2006). Déry and Wood (2005) have noted that the decrease in discharge in northern Canadian rivers is consistent with a decreasing trend in the CRU precipitation data set over the period 1964-2003. In contrast, Berezovskaya et al. (2004) have noted that the CRU precipitation data set, along with other precipitation data sets, prescribe trends that are opposite those observed for the discharge of the Lena and Yenisei rivers. Because TEM used the CRU data set to prescribe precipitation inputs in this study, the representation of precipitation amounts, timing, and trends may largely account for the inability of TEM to capture the observed discharges in some Arctic rivers and the observed trends in discharge of Eurasian rivers during the latter part of the 20th century. The inability of our simulations to capture the recent increases in discharge rates observed in some Arctic rivers suggests that our analyses may be underestimating the associated trends in terrestrial DOC loading in these rivers.

\section{Relative importance of terrestrial carbon dynamics and hydrology}

Our simulation study of the pan-Arctic watershed suggests that while many environmental factors influence terrestrial DOC loading, climate, and wildfire have the most important effects. While wildfire primarily influences terrestrial DOC loading by reducing carbon stored on the landscape, climate influences this loading by effects on both terrestrial carbon dynamics and hydrology. A comparison of terrestrial DOC loading estimated by historical changes in water yield alone to estimates based on changes in both water yield and

TABLE 5. Precipitation and TEM estimates of evapotranspiration, river discharge, and terrestrial DOC loading for large Arctic river basins for the period 1900-2006.

\begin{tabular}{lrrrrr}
\hline \hline & \multicolumn{4}{c}{ Water $\left(\mathrm{km}^{3} / \mathrm{yr}\right)$} & $\begin{array}{c}\text { Terrestrial } \\
\text { DOC loading } \\
\text { River basin }\end{array}$ \\
\cline { 2 - 4 } (Gg C/yr)
\end{tabular}


terrestrial DOC (Table 4) suggests that climate-induced changes in hydrology can account for most of the terrestrial loading. Consideration of terrestrial carbon dynamics reduces the "hydrology-alone" estimate of terrestrial DOC loading to the Arctic Ocean by about $3 \%$. The relative importance of hydrology on terrestrial DOC loading, however, varies across the pan-Arctic accounting for $71-134 \%$ of the terrestrial DOC loading among the various watersheds. Thus, terrestrial carbon dynamics enhance the effect of hydrology on terrestrial DOC loading in some watersheds, but compensate for hydrological effects in other watersheds. In the watersheds emptying into the Kara and Laptev Seas, where climate and wildfires have the largest effects on terrestrial DOC loading (Fig. 4), consideration of terrestrial carbon dynamics reduces the hydrology-alone estimate of DOC loading to the Kara Sea by about $4 \%$ and to the Laptev Sea by about 3\%. Thus, most of the effects on DOC loading of wildfire-induced reductions in soil organic matter have been compensated by climateinduced increases in soil organic matter from enhanced NPP or by climate-induced exposure of formerly frozen soil organic matter from permafrost degradation.

In addition to spatial variability, our study of temporal trends also suggests the dominance of hydrology on terrestrial DOC loading, but indicate that the relative importance of terrestrial carbon dynamics and hydrology on terrestrial DOC loading may be changing (Figs. 3-5). A comparison of the DOC loading and river discharge trends indicate that DOC is becoming more concentrated in run-off to river networks after 1964 and the higher concentrations of DOC are more than compensating for the reductions in water yield on terrestrial DOC loading. The increase in DOC concentrations of the run-off is caused by an increased production of DOC associated with the enhanced decomposition rates along with a reduced water yield from the landscape to the river networks after 1964. Thus, while changes in terrestrial carbon dynamics increase the availability of DOC over time, terrestrial DOC loading may become more limited by the availability of water to deliver the DOC to the river network.

As indicated in the previous section, terrestrial DOC loading in this study may be underestimated because of difficulties in simulating river discharge for many panArctic watersheds. If the trends in terrestrial DOC loading are assumed not to be limited by water yield and mimic the trends in heterotrophic respiration for the study period, our estimate of terrestrial DOC loading increases by about $2 \%$ to be $32.6 \mathrm{Tg} \mathrm{C} / \mathrm{yr}$ over the time period 1900-2006 and 37.2 Tg C/yr for the time period 1997-2006 reported by McGuire et al. (2010).

\section{The role of in-stream carbon dynamics}

Similar to other studies (e.g., Aikenhead and McDowell 2000, Harrison et al. 2005), we assume that the riverine export of DOC could be totally explained by terrestrial DOC loading in this study. The tendency of TEM to overestimate riverine DOC export suggests that not all of the carbon loaded into the river networks from terrestrial ecosystems reaches the Arctic Ocean. Instream processing of DOC through microbial degradation, photo-oxidation, and flocculation with subsequent burial (e.g., Tranvik et al. 2009) can decrease the amount of DOC that reaches the ocean. While the cool temperatures, turbidity, and short residence time of the spring freshet may limit in-stream processing of DOC and DOC may be more refractory during the summer (Holmes et al. 2008), our results suggest that the influence of in-stream carbon dynamics on DOC degradation and loss at other times of the year cannot be totally dismissed. In addition, a peak in bacterial production in an Arctic lake associated with the large inputs of labile DOC from terrestrial ecosystems during the spring freshet (Crump et al. 2003) indicates that a considerable amount of in-stream DOC processing may still be occurring during the spring freshet even with cool $\left(4^{\circ} \mathrm{C}\right)$ water temperatures.

In a recent empirical study, Lauerwald et al. (2012) have estimated that some North American watersheds at the southern end of our study area may lose $25 \%$ or more of their terrestrial-derived DOC from in-stream processing before the river water reaches the oceans. If $25 \%$ of our estimated terrestrial DOC loading is assumed to be lost to in-stream processing, our estimates of riverine DOC export become more comparable to the observations in the Lena, Kolyma, and Mackenzie rivers, but less comparable to the observations in the Yukon, Pechora, and Northern Dvina rivers. In addition, our estimates of riverine DOC export to the Arctic Ocean would be less comparable to those developed by other studies. While addressing the other issues discussed earlier may help resolve these remaining underestimates of DOC export, little information is really known about how in-stream processing of DOC may vary within and among pan-Arctic watersheds or over time.

Besides DOC degradation, in-stream autotrophic production also contributes DOC to a river network, especially during the summer (Crump et al. 2003, Zou et al. 2006). This in-stream DOC production would, to some degree, offset in-stream losses of terrestrially derived DOC in the river.

\section{Conclusions}

Although estimates by our process-based model indicate that allochthonous inputs of DOC to panArctic river networks are about the same magnitude as riverine DOC export to the Arctic Ocean, comparison of model estimates to observations also indicates the existence of substantial uncertainties associated with model parameterization, driving data, and conceptual issues that hinder the ability of our model to reliably estimate the transfer of DOC between land and the Arctic Ocean. Some of these uncertainties may be 
reduced with the acquisition of better data to parameterize the model, particularly data associated with the production and consumption of DOC within the soil profile, the transfer of DOC from land to headwater streams, in-stream carbon dynamics, carbon dynamics of larch-dominated ecosystems in eastern Siberia and peatlands in western Russia, and data to determine the role of industrial organic effluents on carbon budgets of rivers in western Russia. Other uncertainties, such as the spatial distribution of precipitation (and perhaps air temperature) and its temporal trends, may be more difficult to address.

Given these uncertainties, our analyses suggest that (1) terrestrially derived DOC is a dominant component of river DOC export to the Arctic Ocean, but the influence of in-stream carbon dynamics on this export cannot be ignored; (2) terrestrial DOC loading is correlated with many environmental factors, but changes in DOC loading over the 20th century are primarily a result of climate-induced increases in runoff; (3) these increases are moderated by reductions in terrestrial DOC loading associated with the loss of soil organic carbon from wildfires; and (4) warming-induced increases in decomposition rates and permafrost degradation may cause terrestrial carbon dynamics to enhance DOC availability, but changes in terrestrial DOC loading in the future will depend more on changes in the underlying hydrology.

\section{ACKNOWLEDGMENTS}

We thank the University of New Hampshire, EOS-WEBSTER Earth Science Information Partner (ESIP) for providing the land use (row-crop agriculture, pastures, and timber harvest) time-series data used in the analysis. We also thank three anonymous reviewers for comments on previous versions of the paper. This study was supported, in part, by the U.S. National Science Foundation under grants ARC-0531047, ARC-0531082, ARC-0531119, ARC-0554811, and ARC0652838; the U.S. Environmental Protection Agency under grant R833261; the U.S. Department of Energy under grant DE-FG02-08ER64597; and the U.S. National Aeronautics and Space Administration under grant NNX09A126G.

\section{Literature Cited}

Aikenhead, J. A., and W. H. McDowell. 2000. Soil C:N ratio as a predictor of annual riverine DOC flux at local to global scales. Global Biogeochemical Cycles 14(1):127-138.

Aikenhead-Peterson, J. A., J. E. Alexander, and T. A. Clair. 2005. Dissolved organic carbon and dissolved organic nitrogen export from forested watersheds in Nova Scotia: identifying controlling factors. Global Biogeochemical Cycles 19:GB4016.

Aikenhead-Peterson, J. A., W. H. McDowell, and J. C. Neff. 2003. Sources, production and regulation of allocthonous dissolved organic matter inputs to surface waters. Pages 25 70 in S. Findlay and R. L. Sinsabaugh, editors. Aquatic ecosystems: interactivity of dissolved organic matter. Academic Press, San Diego, California, USA.

Aufdenkampe, A. K., E. Mayorga, P. A. Raymond, J. M. Melack, S. C. Doney, S. R. Alin, R. E. Aalto, and K. Yoo. 2011. Riverine coupling of biogeochemical cycles between land, oceans, and atmosphere. Frontiers in Ecology and the Environment 9:53-60.
Balshi, M. S., et al. 2007. The role of historical fire disturbance in the carbon dynamics of the pan-boreal region: a processbased analysis. Journal of Geophysical Research 112:G02029.

Berezovskaya, S., D. Yang, and D. L. Kane. 2004. Compatibility analysis of precipitation and runoff trends over the large Siberian watersheds. Geophysical Research Letters 31:L21502.

Betts, E. F., and J. B. Jones, Jr. 2009. Impact of wildfire on stream nutrient chemistry and ecosystem metabolism in boreal forest catchments of interior Alaska. Arctic, Antarctic, and Alpine Research 41:407-417.

Billett, M. F., S. M. Palmer, D. Hope, C. Deacon, R. StoretonWest, K. J. Hargreaves, C. Flechard, and D. Fowler. 2004. Linking land-atmosphere-stream carbon fluxes in a lowland peatland system. Global Biogeochemical Cycles 18:GB1024.

Clein, J. S., A. D. McGuire, E. S. Euskirchen, and M. Calef. 2007. The effects of different climate input datasets on simulated carbon dynamics in the western Arctic. Earth Interactions 11(12): 1-24.

Clein, J. S., A. D. McGuire, X. Zhang, D. W. Kicklighter, J. M. Melillo, S. C. Wofsy, P. G. Jarvis, and J. M. Massheder. 2002. Historical and projected carbon balance of mature black spruce ecosystems across North America: the role of carbon-nitrogen interactions. Plant and Soil 242(1):15-32.

Crump, B. C., G. W. Kling, M. Bahr, and J. E. Hobbie. 2003. Bacterioplankton community shifts in an arctic lake correlate with seasonal changes in organic matter source. Applied and Environmental Microbiology 69(4):2253-2268.

Déry, S. J., M. A. Hernández-Henríquez, J. E. Burford, and E. F. Wood. 2009. Observational evidence of an intensifying hydrological cycle in northern Canada. Geophysical Research Letters 36:L13402.

Déry, S. J., M. Stieglitz, E. C. McKenna, and E. F. Wood. 2005. Characteristics and trends of river discharge into Hudson, James, and Ungava Bays, 1964-2000. Journal of Climate 18:2540-2557.

Déry, S. J., and E. F. Wood. 2005. Decreasing river discharge in northern Canada. Geophysical Research Letters 32:L10401.

De Wit, H. A., J. Mulder, A. Hindar, and L. Hole. 2007. Longterm increase in dissolved organic carbon in streamwaters in Norway is response to reduced acid deposition. Environmental Science and Technology 41:7706-7713.

Dittmar, T., and G. Kattner. 2003. The biogeochemistry of the river and shelf ecosystem of the Arctic Ocean: a review. Marine Chemistry 83:103-120.

Dornblaser, M. M., and R. G. Striegl. 2007. Nutrient (N, P) loads and yields at multiple scales and subbasin types in the Yukon River basin, Alaska. Journal of Geophysical Research 112:G04S57.

Dye, D. G., and C. J. Tucker. 2003. Seasonality and trends of snow cover, vegetation index, and temperature in northern Eurasia. Geophysical Research Letters 30:1405.

Dyurgerov, M. B., and C. L. Carter. 2004. Observational evidence of increases in freshwater inflow to the Arctic Ocean. Arctic, Antarctic, and Alpine Research 36(1):117122.

Euskirchen, E. S., et al. 2006. Importance of recent shifts in soil thermal dynamics on growing season length, productivity, and carbon sequestration in terrestrial high-latitude ecosystems. Global Change Biology 12:731-750.

Euskirchen, E. S., A. D. McGuire, and F. S. Chapin, III. 2007. Energy feedbacks of northern high-latitude ecosystems to the climate system due to reduced snow cover during 20th century warming. Global Change Biology 13:2425-2438.

Felzer, B., D. Kicklighter, J. Melillo, C. Wang, Q. Zhuang, and R. Prinn. 2004. Effects of ozone on net primary production and carbon sequestration in the conterminous United States using a biogeochemistry model. Tellus 56B:230-248. 
Felzer, B., J. Reilly, J. Melillo, D. Kicklighter, M. Sarofim, C. Wang, R. Prinn, and Q. Zhuang. 2005. Future effects of ozone on carbon sequestration and climate change policy using a global biogeochemical model. Climatic Change 73:345-373.

Fenner, N., C. Freeman, M. A. Lock, H. Harmens, B. Reynolds, and T. Sparks. 2007. Interactions between elevated $\mathrm{CO}_{2}$ and warming could amplify DOC exports from peatland catchments. Environmental Science and Technology 41:3146-3152.

Finlay, J., J. Neff, S. Zimov, A. Davydova, and S. Davydov. 2006. Snowmelt dominance of dissolved organic carbon in high-latitude watersheds: implications for characterization and flux of river DOC. Geophysical Research Letters 33:L10401.

Flannigan, M. D., and J. Little. 2005. Canada large fire database, 1959-1999. edited. Canadian Forest Service, Edmonton, Alberta, Canada.

Frauenfeld, O. W., T. Zhang, R. G. Barry, and D. Gilichinsky. 2004. Interdecadal changes in seasonal freeze and thaw depths in Russia. Journal of Geophysical Research 109:D05101.

Frey, K. E., and J. W. McClelland. 2009. Impacts of permafrost degradation on arctic river biogeochemistry. Hydrological Processes 23:169-182.

Frey, K. E., and L. C. Smith. 2005. Amplified carbon release from vast West Siberian peatlands by 2100. Geophysical Research Letters 32:L09401.

Friedlingstein, P., et al. 2006. Climate-carbon cycle feedback analysis: results from the $\mathrm{C}^{4} \mathrm{MIP}$ model intercomparison. Journal of Climate 19:3337-3353.

Futter, M. N., and H. A. de Wit. 2008. Testing seasonal and long-term controls of streamwater DOC using empirical and process-based models. Science of the Total Environment 407:698-707.

Goetz, S. J., A. G. Bunn, G. I. Fiske, and R. A. Houghton. 2005. Satellite-observed photosynthetic trends across boreal North America associated with climate and fire disturbance. Proceedings of the National Academy of Sciences USA 102:13521-13525.

Gordeev, V. V., E. N. Andreeva, A. P. Lisitzin, H. H. Kremer, W. Salomons, and J. I. Marshall Crossland. 2006. Russian Arctic basins. LOICZ Reports and Studies No. 29. LOICZ, Geesthacht, Germany.

Gordeev, V. V., and M. D. Kravchishina. 2009. River flux of dissolved organic carbon (DOC) and particulate organic carbon (POC) to the Arctic Ocean: what are the consequences of the global changes. Pages 145-160 in J. C. J. Nihoul and A. G. Kostianoy, editors. Influence of climate change on the changing Arctic and sub-Arctic conditions. Springer, New York, New York, USA.

GSDTG (Global Soil Dataset Task Group). 2000. Global gridded surfaces of selected soil characteristics. International Geosphere-Biosphere Programme Data and Information System, Oak Ridge, Tennessee, USA

Guo, L., Y. Cai, C. Belzile, and R. W. Macdonald. 2012. Sources and export fluxes of inorganic and organic carbon and nutrient species from the seasonally ice-covered Yukon River. Biogeochemistry 107:187-206.

Guo, L., and R. W. Macdonald. 2006. Source and transport of terrigenous organic matter in the upper Yukon River: evidence from isotope $\left({ }^{13} \mathrm{C},{ }^{14} \mathrm{C}\right.$ and $\left.{ }^{15} \mathrm{~N}\right)$ composition of dissolved, colloidal and particulate phases. Global Biogeochemical Cycles 20:GB2011.

Harrison, J. A., N. Caraco, and S. P. Seitzinger. 2005. Global patterns and sources of dissolved organic matter export to the coastal zone: results from a spatially explicit global model. Global Biogeochemical Cycles 19:GB4S04 .
Hayes, D. J., A. D. McGuire, D. W. Kicklighter, K. R. Gurney, T. J. Burnside, and J. M. Melillo. 2011. Is the northern highlatitude land-based $\mathrm{CO}_{2}$ sink weakening? Global Biogeochemical Cycles 25:GB3018.

Holmes, R. M., et al. 2012. Seasonal and annual fluxes of nutrients and organic matter from large rivers to the Arctic Ocean and surrounding seas. Estuaries and Coasts 35:369382.

Holmes, R. M., J. W. McClelland, P. A. Raymond, B. B. Frazer, B. J. Peterson, and M. Stieglitz. 2008. Lability of DOC transported by Alaskan rivers to the Arctic Ocean. Geophysical Research Letters 35:L03402.

Holmes, R. M., B. J. Peterson, V. V. Gordeev, A. V. Zhulidov, M. Maybeck, R. B. Lammers, and C. J. Vörösmarty. 2000. Flux of nutrients from Russian rivers to the Arctic Ocean: can we establish a baseline against which to judge future changes? Water Resources Research 36(8):2309-2320.

Hurtt, G. C., S. Frolking, M. G. Fearon, B. Moore, E. Shevliakova, S. Malyshev, S. W. Pacala, and R. A. Houghton. 2006. The underpinnings of land-use history: three centuries of global gridded land-use transitions, wood harvest activity, and resulting secondary lands. Global Change Biology 12:1208-1229.

Kahle, M., M. Kleber, and R. Jahn. 2004. Retention of dissolved organic matter by phyllosilicate and soil clay fractions in relation to mineral properties. Organic Geochemistry 35:269-276.

Kalbitz, K., S. Solinger, J.-H. Park, B. Michalzik, and E. Matzner. 2000. Controls on the dynamics of dissolved organic matter in soils: a review. Soil Science 165:277-304.

Kasischke, E. S., and M. R. Turetsky. 2006. Recent changes in the fire regime across the North American boreal regionspatial and temporal patterns of burning across Canada and Alaska. Geophysical Research Letters 33:L09703.

Keeling, R. F., S. C. Piper, A. F. Bollenbacher, and S. J. Walker. 2009. Monthly atmospheric $\mathrm{CO}_{2}$ records from sites in the SIO air sampling network. Carbon Dioxide Information Analysis Center, Oak Ridge National Laboratory, U.S. Department of Energy, Oak Ridge, Tennessee, USA. http:// cdiac.ornl.gov/ftp/trends/co2/

Köhler, H., B. Meon, V. V. Gordeev, A. Spitzy, and R. M. W. Amon. 2003. Dissolved organic matter (DOM) in the estuaries of $\mathrm{Ob}$ and Yenisei and the adjacent Kara Sea, Russia. Pages 281-308 in R. Stein, K. Fahl, D. K. Fütterer, E. Galimov, and O. Stepanets, editors. Siberian river runoff in the Kara Sea: characterisation, quantification, variability and environmental significance. Proceedings in Marine Sciences. Volume 6. Elsevier, Amsterdam, The Netherlands.

Lammers, R. B., A. I. Shiklomanov, C. J. Vörösmarty, B. M. Fekete, and B. J. Peterson. 2001. Assessment of contemporary Arctic river runoff based on observational discharge records. Journal of Geophysical Research 106 (D4):33213334.

Lamontagne, S., R. Carigan, P. D'Arcy, Y. T. Prairie, and D. Paré. 2000. Element export in runoff from eastern Canadian Boreal Shield drainage basins following forest harvesting and wildfires. Canadian Journal of Fisheries and Aquatic Sciences 57(Supplement 2):118-128.

Lauerwald, R., J. Hartmann, W. Ludwig, and N. Moosdorf. 2012. Assessing the nonconservative fluvial fluxes of dissolved organic carbon in North America. Journal of Geophysical Research 117:G01027. http://dx.doi.org/10. 1029/2011JG001820

Liski, J., A. V. Korotkov, C. F. L. Prins, T. Karjalainen, D. G. Victor, and P. E. Kauppi. 2003. Increased carbon sink in temperate and boreal forests. Climatic Change 61:89-99.

Loveland, T. R., B. C. Reed, J. F. Brown, D. O. Ohlen, Z. Zhu, L. Yang, and J. W. Merchant. 2000. Development of a global 
land cover characteristics database and IGBP DISCover from $1 \mathrm{~km}$ AVHRR data. International Journal of Remote Sensing 21(6-7):1303-1330.

MacLean, R., M. W. Oswood, J. G. Irons III, and W. H. McDowell. 1999. The effect of permafrost on stream biogeochemistry: a case study of two streams in the Alaskan (U.S.A.) taiga. Biogeochemistry 47:239-267.

Manizza, M., M. J. Follows, S. Dutkiewicz, J. W. McClelland, D. Menemenlis, C. N. Hill, A. Townsend-Small, and B. J. Peterson. 2009. Modeling transport and fate of riverine dissolved organic carbon in the Arctic Ocean. Global Biogeochemical Cycles 23:GB4006.

McClelland, J. W., S. J. Déry, B. J. Peterson, R. M. Holmes, and E. F. Wood. 2006. A pan-arctic evaluation of changes in river discharge during the latter half of the 20th century. Geophysical Research Letters 33:L06715.

McClelland, J. W., R. M. Holmes, K. H. Dunton, and R. W. Macdonald. 2012. The Arctic Ocean estuary. Estuaries and Coasts 35:353-368

McClelland, J. W., R. M. Holmes, B. J. Peterson, and M. Stieglitz. 2004. Increasing river discharge in the Eurasian Arctic: consideration of dams, permafrost thaw and fires as potential agents of change. Journal of Geophysical Research 109:D18102.

McClelland, J. W., M. Stieglitz, F. Pan, R. M. Holmes, and B. J. Peterson. 2007. Recent changes in nitrate and dissolved organic carbon export from the upper Kuparuk River, North Slope, Alaska. Journal of Geophysical Research 112: G04S60.

McDonald, K. C., J. S. Kimball, E. Njoku, R. Zimmermann, and M. Zhao. 2004. Variability in springtime thaw in the terrestrial high latitudes: monitoring a major control on the biospheric assimilation of atmospheric $\mathrm{CO}_{2}$ with spaceborne microwave remote sensing. Earth Interactions 8(20):1-23.

McGuire, A. D., L. G. Anderson, T. R. Christensen, S. Dallimore, L. Guo, D. J. Hayes, M. Heimann, T. D. Lorenson, R. W. Macdonald, and N. Roulet. 2009. Sensitivity of the carbon cycle in the Arctic to climate change. Ecological Monographs 79:523-555.

McGuire, A. D., et al. 2010. An analysis of the carbon balance of the Arctic Basin from 1997 to 2006. Tellus B 62:455-474.

McGuire, A. D., J. M. Melillo, L. A. Joyce, D. W. Kicklighter, A. L. Grace, B. Moore III, and C. J. Vorosmarty. 1992 Interactions between carbon and nitrogen dynamics in estimating net primary productivity for potential vegetation in North America. Global Biogeochemical Cycles 6:101-124.

McGuire, A. D., J. M. Melillo, D. W. Kicklighter, Y. Pan, X Xiao, J. Helfrich, B. Moore III, C. J. Vorosmarty, and A. L. Schloss. 1997. Equilibrium responses of global net primary production and carbon storage to doubled atmospheric carbon dioxide: Sensitivity to changes in vegetation nitrogen concentration. Global Biogeochemical Cycles 11:173-189.

McGuire, A. D., et al. 2001. Carbon balance of the terrestrial biosphere in the twentieth century: analyses of $\mathrm{CO}_{2}$, climate and land-use effects with four process-based ecosystem models. Global Biogeochemical Cycles 15(1):183-206.

Michalzik, B., E. Tipping, J. Mulder, J. F. Gallardo Lancho, E. Matzner, C. L. Bryant, N. Clarke, S. Lofts, and M. A. Vicente Esteban. 2003. Modelling the production and transport of dissolved organic carbon in forest soils. Biogeochemistry $66: 241-264$.

Mitchell, T. D., and P. D. Jones. 2005. An improved method of constructing a database of monthly climate observations and associated high-resolution grids. International Journal of Climatology 25:693-712.

Monteith, D. T., et al. 2007. Dissolved organic carbon trends resulting from changes in atmospheric deposition chemistry. Nature 450:537-541.
Neff, J. C., and G. P. Asner. 2001. Dissolved organic carbon in terrestrial ecosystems: synthesis and a model. Ecosystems $4: 29-48$.

Neff, J. C., and D. U. Hooper. 2002. Vegetation and climate controls on potential $\mathrm{CO}_{2}, \mathrm{DOC}$ and DON production in northern latitude soils. Global Change Biology 8:872884.

NGDC. 1994. Terrain-Base. Version 1.1. Five-minute digital terrain model data. National Geophysical Data Center, Boulder, Colorado, USA.

Opsahl, S., R. Benner, and R. M. W. Amon. 1999. Major flux of terrigenous dissolved organic matter through the Arctic Ocean. Limnology and Oceanography 44:2017-2023.

Payette, S., A. Delwaide, M. Caccianga, and M. Beauchemin. 2004. Accelerated thawing of subarctic peatland permafrost over the last 50 years. Geophysical Research Letters 31:L18208.

Peterson, B. J., R. M. Holmes, J. W. McClelland, C. J. Vörösmarty, R. B. Lammers, A. I. Shiklomanov, I. A. Shiklomanov, and S. Rahmstorf. 2002. Increasing river discharge to the Arctic Ocean. Science 298:2171-2173.

Petrone, K. C., J. B. Jones, L. D. Hinzman, and R. D. Boone. 2006. Seasonal export of carbon, nitrogen, and major solutes from Alaskan catchments with discontinuous permafrost. Journal of Geophysical Research 111:G02020.

Prokushkin, A. S., G. Gleixner, W. H. McDowell, S. Ruehlow, and E.-D. Schulze. 2007. Source- and substrate-specific export of dissolved organic matter from permafrost-dominated forested watershed in central Siberia. Global Biogeochemical Cycles 21:GB4003.

Prokushkin, A. S., S. Hobara, and S. G. Prokushkin. 2010. Behavior of dissolved organic carbon in larch ecosystems. Pages 205-228. in A. Osawa, O. A. Zyryanova, Y. Matsuura, T. Kajimoto, and R. W. Wein, editors. Permafrost ecosystems: Siberian larch forests. Ecological studies. Volume 209. Springer, New York, New York, USA.

Prokushkin, A. S., M. Kawahigashi, and I. V. Tokareva. 2009. Global warming and dissolved organic carbon release from permafrost soils. Pages 237-250 in R. Margesin, editor. Permafrost soils. Soil biology. Volume 16. Springer-Verlag, Berlin, Germany.

Prokushkin, A. S., O. S. Pokrovsky, L. S. Shirokova, M. A. Korets, J. Viers, S. G. Prokushkin, R. M. W. Amon, G. Guggenberger, and W. H. McDowell. 2011. Sources and the flux pattern of dissolved carbon in rivers of the Yenisey basin draining the Central Siberian Plateau. Environmental Research Letters 6:045212.

Qualls, R. G., and B. L. Haines. 1992. Biodegradability of dissolved organic matter in forest throughfall, soil solution and stream water. Soil Science Society of America Journal 56:578-586.

Raich, J. W., E. B. Rastetter, J. M. Melillo, D. W. Kicklighter, P. A. Steudler, B. J. Peterson, A. L. Grace, B. Moore III, and C. J. Vorosmarty. 1991. Potential net primary productivity in South America: application of a global model. Ecological Applications 1:399-429.

Randerson, J. T., G. R. van der Werf, L. Giglio, G. J. Collatz, and P. S. Kasibhatla. 2006. Global fire emissions database. Version 2. Oak Ridge National Laboratory, Oak Ridge, Tennessee, USA.

Raymond, P. A., J. W. McClelland, R. M. Holmes, A. V. Zhulidov, K. Mull, B. J. Peterson, R. G. Striegl, G. R. Aiken, and T. Y. Gurtovaya. 2007. Flux and age of dissolved organic carbon exported to the Arctic Ocean: a carbon isotopic study of the five largest arctic rivers. Global Biogeochemical Cycles 21:GB4011.

Roulet, N., and T. R. Moore. 2006. Browning the waters. Nature 444:283-284. 
Schuur, E. A. G., B. Abbott, and the Permafrost Carbon Network. 2011. High risk of permafrost thaw. Nature 480:32-33.

Schuur, E. A. G., et al. 2008. Vulnerability of permafrost carbon to climate change: implications for the global carbon cycle. BioScience 58:701-714.

Serreze, M. C., D. H. Bromwich, M. P. Clark, A. J. Etringer, T. Zhang, and R. Lammers. 2003. Large-scale hydro-climatology of the terrestrial Arctic drainage system. Journal of Geophysical Research 108(D2):8160.

Shvidenko, A., and S. Nilsson. 2002. Dynamics of Russian forests and the carbon budget in 1961-1998: an assessment based on long-term forest inventory data. Climatic Change 55:5-37.

Sickman, J. O., M. J. Zanoli, and H. L. Mann. 2007. Effects of urbanization on organic carbon loads in the Sacramento River, California. Water Resources Research 43:W11422.

Sitch, S., P. M. Cox, W. J. Collins, and C. Huntingford. 2007. Indirect radiative forcing of climate change through ozone effects on the land-carbon sink. Nature 448:791-794.

Sobczak, W. V., and S. Findlay. 2002. Variation in bioavailability of dissolved organic carbon among stream hyporheic flowpaths. Ecology 83:3194-3209.

Soja, A. J., N. M. Tchebakova, N. H. F. French, M. D. Flannigan, H. H. Shugart, B. J. Stocks, A. I. Sukhinin, E. I. Parfenova, F. S. Chapin, III, and P. W. Stackhouse, Jr. 2007. Climate-induced boreal forest change: predictions versus current observations. Global and Planetary Change 56:274296.

Sokal, R. R., and F. J. Rohlf. 1969. Biometry. W. H. Freeman and Company, San Francisco, California, USA.

Sokolov, A. P., D. W. Kicklighter, J. M. Melillo, B. S. Felzer, C. A. Schlosser, and T. W. Cronin. 2008. Consequences of considering carbon-nitrogen interactions on the feedbacks between climate and the terrestrial carbon cycle. Journal of Climate 21:3776-3796.

Spencer, R. G. M., G. R. Aiken, K. D. Butler, M. M. Dornblaser, R. G. Striegl, and P. J. Hernes. 2009. Utilizing chromophoric dissolved organic matter measurements to derive export and reactivity of dissolved organic carbon exported to the Arctic Ocean: a case study of the Yukon River, Alaska. Geophysical Research Letters 36:L06401.

Spencer, R. G. M., G. R. Aiken, K. P. Wickland, R. G. Striegl, and P. J. Hernes. 2008. Seasonal and spatial variability in dissolved organic matter quantity and composition from the Yukon River basin, Alaska. Global Biogeochemical Cycles 22:GB4002.

Striegl, R. G., G. R. Aiken, M. M. Dornblaser, P. A. Raymond, and K. P. Wickland. 2005. A decrease in dischargenormalized DOC export by the Yukon River during summer through autumn. Geophysical Research Letters 32:L21413.

Striegl, R. G., M. M. Dornblaser, G. R. Aiken, K. P. Wickland, and P. A. Raymond. 2007. Carbon export and cycling by the Yukon, Tanana, and Porcupine rivers, Alaska, 2001-2005. Water Resources Research 43:W02411.

Sukhinin, A. I., et al. 2004. AVHRR-based mapping of fires in Russia: new products for fire management and carbon cycle studies. Remote Sensing of the Environment 93:546-564.
Tarnocai, C., J. G. Canadell, E. A. G. Schuur, P. Kuhry, G. Mazhitova, and S. Zimov. 2009. Soil organic carbon pools in the northern circumpolar permafrost region. Global Biogeochemical Cycles 23:GB2023.

Thornton, P. E., J.-F. Lamarque, N. A. Rosenbloom, and N. M. Mahowald. 2007. Influence of carbon-nitrogen cycle coupling on land model response to $\mathrm{CO}_{2}$ fertilization and climate variability. Global Biogeochemical Cycles 21: GB4018.

Tian, H., J. M. Melillo, D. W. Kicklighter, A. D. McGuire, and J. Helfrich. 1999. The sensitivity of terrestrial carbon storage to historical climate variability and atmospheric $\mathrm{CO}_{2}$ in the United States. Tellus B 51:414-452.

Tranvik, L. J., et al. 2009. Lakes and reservoirs as regulators of carbon cycling and climate. Limnology and Oceanography 54:2298-2314.

van der Werf, G. R., J. T. Randerson, L. Giglio, G. J. Collatz, P. S. Kasibhatla, and A. F. Arellano, Jr. 2006. Interannual variability in global biomass burning emissions from 1997 to 2004. Atmospheric Chemistry and Physics 6(11):3423-3441.

Van Drecht, G., A. F. Bouwman, J. M. Knoop, A. H. W. Beusen, and C. R. Meinardi. 2003. Global modeling of the fate of nitrogen from point and nonpoint sources in soils, groundwater, and surface water. Global Biogeochemical Cycles 17:1115.

Vörösmarty, C. J., B. Moore III, A. L. Grace, M. P. Gildea, J. M. Melillo, B. J. Peterson, E. B. Rastetter, and P. A. Steudler. 1989. Continental scale models of water balance and fluvial transport: an application to South America. Global Biogeochemical Cycles 3:241-265.

Wilson, H. F., and M. A. Xenopoulos. 2008. Effects of agricultural land use on the composition of fluvial dissolved organic matter. Nature Geoscience 2:37-41.

Worrall, F., T. Burt, and J. Adamson. 2004. Can climate change explain increases in DOC flux from upland peat catchments? Science of the Total Environment 326:95-112.

Yano, Y., W. H. McDowell, and J. D. Aber. 2000. Biodegradable dissolved organic carbon in forest soil solution and effects of chronic nitrogen deposition. Soil Biology and Biochemistry 32:1743-1751.

Zaehle, S., P. Friedlingstein, and A. D. Friend. 2010. Terrestrial nitrogen feedbacks may accelerate future climate change. Geophysical Research Letters 37:L01401.

Zhuang, Q., A. D. McGuire, J. M. Melillo, J. S. Clein, R. J. Dargaville, D. W. Kicklighter, R. B. Myneni, J. Dong, V. E. Romanovsky, J. Harden, and J. E. Hobbie. 2003. Carbon cycling in extratropical terrestrial ecosystems of the Northern Hemisphere during the 20th Century: a modeling analysis of the influences of soil thermal dynamics. Tellus B 55:751-776. Ziegler, A. D., J. Sheffield, E. P. Maurer, B. Nussen, E. F. Wood, and D. P. Lettenmaier. 2003. Detection of intensification in global- and continental-scale hydrological cycles: temporal scale of evaluation. Journal of Climate 16:535-547.

Zou, L., M.-Y. Sun, and L. Guo. 2006. Temporal variations of organic carbon inputs into the upper Yukon River: evidence from fatty acids and their stable carbon isotope compositions in dissolved, colloidal and particulate phases. Organic Geochemistry 37:944-956.

\section{Supplemental Material}

\section{Appendix A}

Modifications of the Terrestrial Ecosystem Model to better represent decomposition and soil moisture dynamics in Arctic ecosystems (Ecological Archives A023-089-A1). 


\section{Appendix C}

Detailed evaluation of simulated terrestrial DOC loading and river discharge (Ecological Archives A023-089-A3).

\section{Appendix D}

Detailed description of regional variations in simulated terrestrial DOC loading, water yield, river discharge, and deepening of the active layer (Ecological Archives A023-089-A4). 